\title{
Observations on the Isturgia limbaria (Fabricius, 1775) / roraria (Fabricius, 1776) complex (Lepidoptera, Geometridae, Ennominae)
}

\author{
Claudio Flamigni ${ }^{1}$, Gabriele Fiumi ${ }^{2}$ \\ 1 via delle Belle Arti 21, I-40126Bologna, Italy; claudio.flamigni@alice.it \\ 2 via Decio Raggi 167, I-47121 Forli, Italy; gabfium@tiscali.it \\ http://zoobank.org/88BBA56C-CEFF-42DA-A452-0DBF104A3DA2
}

Received 13 September 2019; accepted 24 April 2020; published: 4 August 2020

Subject Editor: Sven Erlacher.

\begin{abstract}
The Isturgia limbaria (Fabricius, 1775)/roraria (Fabricius, 1776) complex is analyzed, taking into consideration the external morphology of the adults (coloration and pattern of upperside and underside of wings), the morphology of the female genitalia (signum and lamella postvaginalis), of the tympanal organs and of the preimaginal stages, as well as molecular data. Based on the molecular data and morphology of signum and tympanic organs, the populations of this complex can be divided into two groups, one more western (with the taxa limbaria s. str. and delimbaria), distributed east to north-western Italy and part of Germany, and one more eastern (with the taxa roraria s. str., rablensis and anzascaria), distributed west to northern and eastern Piedmont (Italy) and north-eastern and south-eastern Germany. However, there are no consistent differences between the two groups in the diagnostic characters used until now to identify the two taxa (pattern of the wing upperside and underside). Although there is a considerable genetic distance between these two groups, the correlation between molecular differences and morphological characters (size of the signum and presence-or absence-of a roundish lobe in the bullae tympani) is not completely constant and the two groups of populations are not completely separated from each other: some populations of the northern Apennines (taxon delimbaria) cannot be clearly attributed to one or the other group. In the absence of constant morphological characters associated with the molecular differences and in the presence of Italian populations with intermediate characters, we suggest that the different taxa of this complex be considered as subspecies of the same species, as already proposed by Povolný and Moucha $(1957,1959)$. However, the data available do not allow definitive clarification of the taxonomic problem and further research is necessary.
\end{abstract}

\section{Introduction}

Fabricius described Phalaena limbaria and P. roraria respectively in 1775 and 1776. Zeller (1868) described Fidonia limbaria var. rablensis (from the Julian Alps), as intermediate between roraria and limbaria, but attributed it to the latter based on the characteristics of the wing underside. Prout (1915) and Wehrli (1940) treated this taxon as Isturgia limbaria var. rablensis, distributed from northern Italy to Albania and to the southern Carpathians. Povolný and Moucha $(1957,1959)$ downgraded roraria to a subspecies of limbaria: in their opinion the former is distributed in central and south-eastern Europe, the latter mainly in western Europe, but the populations from the Balkans and the southern Alps (taxon rablensis) have mixed characters and cannot be attributed objectively to one or the other; in addition, both limbaria and roraria are very variable and there are no differences in the genitalia, habitat and foodplant. According to these authors in the Riss- 
Würm interglacial period there would still have been a single species, which during the Würm glaciation would have been divided into two groups of populations, confined to different glacial refuges (south-western and south-eastern European). Later, after long isolation, the two groups of populations would have come into contact again. In Central Europe the differentiation due to the isolation period would have been sufficient to prevent hybridization between the two forms, while to the south of the Alps the isolation would have been shorter (or would not have been complete) and therefore hybridization would have been possible. According to the same authors a similar example would be represented by Polyommatus eros eros (Ochsenheimer, 1808) and Polyommatus eros eroides (Frivaldsky, 1835) (Lycaenidae).

Also Patočka (2004) considered roraria as a subspecies of limbaria. In contrast, Lehmann (1990) transferred rablensis from a subspecies of limbaria to a subspecies of roraria, based on Gelbrecht's research, who examined mainly the characteristics of the larvae and pupae and the size of the signum in female genitalia (Gelbrecht, pers. comm.); however, Gelbrecht did not examine specimens from the Julian Alps (locus typicus of rablensis), but only from Bulgaria (Vitosha). His point of view was accepted by Viidalepp (1996) and Beshkov (2001), while Huemer and Tarmann (1993), Flamigni et al. (2007) and Leraut (2009) continued to treat this taxon as Isturgia limbaria rablensis. Hausmann (2001) mentioned and figured southern Alpine populations as a model case for hybridization in the evolutionary history of species complexes.

Based on genetic data, Skou and Sihvonen (2015) attributed the populations from the Balkans and the Julian Alps to roraria, but not those from South Tyrol (Monte Baldo), which grouped in a different genetic cluster but are practically identical to those from the Julian Alps in the wing pattern. Without transferring rablensis from the status of subspecies of limbaria to a subspecies of roraria, they suggested that the limbaria/roraria species complex needs a thorough detailed analysis.

The present study aims to provide a contribution to the clarification of the taxonomic problems still unresolved, through an analysis of the different populations that make up this complex.

\section{Material and methods}

The study is based on material deposited in the collections listed in Table 1 (see section Taxonomy for details on specimens examined). These observations were also supplemented by the examination of images in the literature and on websites. Unpublished information on the morphology of larvae and pupae have been provided by Jörg Gelbrecht (Königs Wusterhausen, Germany).

Taxon delimitation was based on the combined study of external morphology of the adults (coloration and pattern of the upperside and underside wings), morphology of the female genitalia (signum and lamella postvaginalis) and tympanal organs, as well as of molecular data.

For the extraction of the female genitalia and tympanal organs the abdomen was macerated cold in a $20 \% \mathrm{KOH}$ solution for 12 hours. Then the longitudinally sectioned abdomen was stained using chlorazol black-alcohol mixture for two minutes. Genitalia were cleaned in water and mounted on a slide in dimethyl hydantoin formaldehyde (DMHF). Tympanal organs were removed from the abdomen, cleaned and mounted on a slide.

Because the signum is stellate with a more or less elliptical shape, in each specimen the smaller diameter and the larger diameter of this ellipse were measured (both up to the ends of the tips), averaging the two diameters. 
Table 1. Abbreviations of the collections.

\begin{tabular}{ll}
\hline KLM: Landesmuseum Kärnten, Klagenfurt, Austria & RCEF: Research Collection of Egbert Friedrich \\
MNC: Museum für Naturkunde, Chemnitz, Germany & RCGF: Research Collection of Gabriele Fiumi \\
MSNB: Museo civico di Scienze Naturali “E. Caff”, Bergamo, Italy & RCGG: Research Collection of Guido Govi \\
NHMW: Museum of Natural History of Vienna & RCJV: Research Collection of Joachim Viehmann \\
RCAH: Research Collection of Alfred Haslberger & RCSB: Research Collection of Stoyan Beshkov \\
RCBD: Research Collection of Bernard Dardenne & TLMF: Tiroler Landesmuseum Ferdinandeum, Innsbruck, Austria \\
RCCF: Research Collection of Claudio Flamigni & ZSM SNSB: Bavarian State Collection of Zoology, Munich \\
RCCM: Research Collection of Carlo Morandini & (Zoologische Staatssammlung München) \\
\hline
\end{tabular}

For the DNA analyses, one leg was removed from dried specimens. DNA extraction, amplification, and sequencing of the barcode region of the mitochondrial cytochrome c oxidase I (COI) gene (658 base pairs) were carried out in the Canadian Centre for DNA Barcoding, Ontario, Canada, using standard protocols (Ivanova et al. 2006; deWaard et al. 2008). Unfortunately, the barcoding of only one of our specimens (BC ZSM Lep 97046, from Lombardy) was successful. For this research all the data in the BOLD database (Ratnasingham and Hebert 2007) were also used: data on utilized sequences are summarized in Table 2.

The Barcode Index Number (BIN) is an online framework of BOLD database that clusters barcode sequences algorithmically (Ratnasingham and Hebert 2007).

Information on molecular data was provided by A. Hausmann (SNSB-Bavarian State Collection of Zoology, Munich, Germany), who also examined the specimens from the ZSM collection. Sequence divergence was calculated by Hausmann using the Kimura 2-parameter model (Kimura 1980) and the neighbour-joining algorithm (Saitou and Nei 1987), as implemented in BOLD.

\section{Results}

\section{Molecular data}

The results from the molecular analysis are shown in Figure A1 (see Appendix I).

The limbaria/roraria complex genetically splits up into three genetic clusters. BOLD:AAF3598 corresponds to the taxa limbaria s. str. and delimbaria; BOLD:ACX8520 to the westernmost populations of the taxon rablensis (Lombardy and Monte Baldo in Italy, Carinthia in Austria); BOLD:AAF3597 to the remaining populations of rablensis (from the Julians Alps to Bulgaria and Romania) and to the taxon roraria s. str.. The minimum distance of AAF3598 from the other two BINs is 3.95\%, while that between AAF3597 and ACX8520 is 2.0\%. Further information is given in the treatment of single taxa.

Figure 1 shows the distribution of the barcode clusters of the complex limbaria/roraria in northern Italy and southern Austria; Figure 2 the distribution of the taxa of the same complex in northern Italy.

\section{Morphological characters}

The diagnostic characters of I. limbaria and I. roraria are illustrated by Skou and Sihvonen (2015: 98, text-figs 37-40): wings, upperside irrorated with brown scales, terminal area dark brown in limbaria; wings, upperside striated with brown scales, terminal area light brown in roraria; hindwings, underside with radiating whitish lines in limbaria, without whitish lines in roraria. On the basis of these characters, the taxa limbaria s. str. (Figs 3, 8, 13, 18), delimbaria (Figs 4, 9, 14, 19), anzascaria (Figs 5, 10, 15, 20) and roraria s. str. (Figs 7, 12, 17, 22) can be identified without prob- 
Table 2. Barcoded specimens (from BOLD data systems).

\begin{tabular}{|c|c|c|c|c|c|c|}
\hline Taxon & Country & Region & Locality and date & Collector and collection & Specimen ID & $\begin{array}{l}\text { Barcode Index } \\
\text { Number (BIN) }\end{array}$ \\
\hline limbaria s. str. & Germany & Hesse & $\begin{array}{c}\text { Lahn-Dill-Kreis, } \\
\text { Hirzenhain, 4.vii.2002 }\end{array}$ & D. Feierabend leg., RCJV & BC ZFMK Lep 00683 & BOLD:AAF3598 \\
\hline limbaria s. str. & Germany & Thuringia & $\begin{array}{c}\text { Gumpelstadt, Jauchsental, } \\
\text { 11-vi.2006 }\end{array}$ & U. Buechner leg., MNC & SE MNC Lep 00599 & BOLD:AAF3598 \\
\hline limbaria s. str. & Germany & Thuringia & Wahlhausen, 22.v.1998 & R. Rommel leg., MNC & SE MNC Lep 00600 & BOLD:AAF3598 \\
\hline limbaria s. str. & Germany & Bavaria & $\begin{array}{c}\text { Oberpfalz, Schwarzenbach, } \\
\text { 11.v.1994 }\end{array}$ & G. Nowak leg., MNC & SE MNC Lep 00601 & BOLD:AAF3598 \\
\hline limbaria s. str. & France & $\begin{array}{c}\text { Upper } \\
\text { Normandy }\end{array}$ & $\begin{array}{c}\text { Seine Maritime, Anneville- } \\
\text { Ambourville, 22.v.1995 }\end{array}$ & B. Dardenne leg., RCBD & LN-BD1103 & BOLD:AAF3598 \\
\hline delimbaria & Italy & Liguria & $\begin{array}{c}\text { Ligurian Alps, Ventimiglia, } \\
600 \text { m, 27.v. } 2001\end{array}$ & E.O. Bonora leg., RCJV & BC ZFMK Lep 00684 & BOLD:AAF3598 \\
\hline delimbaria & Italy & Tuscany & $\begin{array}{c}\text { Apuan Alps, under Monte } \\
\text { Corchia, Passo Croce, } \\
\text { 18.vi.1999 }\end{array}$ & L. Dapporto leg., ZSM & BC ZSM Lep 63447 & BOLD:AAF3598 \\
\hline rablensis & Italy & Lombardy & $\begin{array}{c}\text { Bergamasque Prealps, } \\
\text { Camerata Cornello, } \\
\text { towards Passo Grialeggio, } \\
\text { 23.vii.2010 }\end{array}$ & $\begin{array}{l}\text { M. Massaro and W. } \\
\text { Zucchelli leg., MSNB }\end{array}$ & BC ZSM Lep 97046 & BOLD:ACX8520 \\
\hline rablensis & Italy & $\begin{array}{l}\text { Trentino- } \\
\text { Alto Adige }\end{array}$ & $\begin{array}{l}\text { Monte Baldo, } 1550 \mathrm{~m}, \\
\text { 8.vi.1994 }\end{array}$ & S. Erlacher leg., MNC & SE MNC Lep 00609 & BOLD:ACX8520 \\
\hline rablensis & Austria & Carinthia & $\begin{array}{c}\text { [Gitschtal], } 46.678 \mathrm{~N}, \\
\text { 13.313E, } 1020 \mathrm{~m}, \\
\text { 29.v.2015 }\end{array}$ & Ch. Wieser leg., KLM & KLM Lep 03479 & BOLD:ACX8520 \\
\hline rablensis & Italy & $\begin{array}{l}\text { Friuli- } \\
\text { Venezia } \\
\text { Giulia }\end{array}$ & $\begin{array}{c}\text { Julian Prealps, Val } \\
\text { Venzonassa, Jof Ungarina } \\
\text { SW side - Malga Confin } \\
\text { W, } 1280 \text { m, 12.vi.2007 }\end{array}$ & P. Huemer leg., TLMF & $\begin{array}{l}\text { TLMF Lep 00212, } \\
\text { TLMF Lep 04447, } \\
\text { TLMF Lep } 04448\end{array}$ & BOLD:AAF3597 \\
\hline rablensis & Bulgaria & $\begin{array}{l}\text { W Stara } \\
\text { Planina } \\
\text { Mts }\end{array}$ & $\begin{array}{l}\text { between Gorni Lom } \\
\text { Village and Midzhur Top, } \\
1425 \mathrm{~m}, 14 . v i i .2009\end{array}$ & S. Beshkov leg., RCSB & BC SB Lep 0017 & BOLD:AAF3597 \\
\hline rablensis & Romania & $\begin{array}{l}\text { Buzău } \\
\text { County }\end{array}$ & $\begin{array}{l}\text { Eastern Carpathians, } \\
\text { Nemira Mountains, } \\
\text { Lassuag, } 1100 \mathrm{~m} \text {, } \\
\text { 22.vi.1996 }\end{array}$ & $\begin{array}{c}\text { S. and.Z. Kovacs leg., } \\
\text { ZSM }\end{array}$ & BC ZSM Lep 73989 & BOLD:AAF3597 \\
\hline rablensis & Romania & $\begin{array}{c}\text { Dâmbovița } \\
\text { County }\end{array}$ & $\begin{array}{l}\text { Southern Carpathians, } \\
\text { Bucegi Mountains, Valea } \\
\text { Jepii, } 1800 \text { m, 7.vi.2007 }\end{array}$ & $\begin{array}{c}\text { S.and.Z. Kovacs leg., } \\
\text { ZSM }\end{array}$ & $\begin{array}{l}\text { BC ZSM Lep 73986, } \\
\text { BC ZSM Lep } 73987\end{array}$ & BOLD:AAF3597 \\
\hline roraria s. str. & Germany & Thuringia & Erlau, Zeltplatz, 4.vii.1999 & S. Erlacher leg., MNC & SE MNC Lep 00605 & BOLD:AAF3597 \\
\hline roraria s. str. & Germany & $\begin{array}{l}\text { Saxony- } \\
\text { Anhalt }\end{array}$ & $\begin{array}{l}\text { Bitterfeld, Marke: } 0.5 \\
\text { km east the motorway } \\
\text { exit Dessau-Süd, } 85 \text { m, } \\
\text { 24.v.2012 }\end{array}$ & J. Gelbrecht leg., ZSM & BC ZSM Lep 91967 & BOLD:AAF3597 \\
\hline roraria s. str. & Germany & Bavaria & Spalt, 6.v.1997 & A. Zoglauer leg., RCJV & BC ZFMK Lep 00685 & BOLD:AAF3597 \\
\hline roraria s. str. & Germany & Bavaria & $\begin{array}{c}\text { Mittelfranken, Roth, Spalt, } \\
400 \mathrm{~m}, 17 . v i i .2007\end{array}$ & A. Zoglauer leg., RCAH & BC ZSM Lep 24010 & BOLD:AAF3597 \\
\hline roraria s. str. & Germany & Bavaria & $\begin{array}{c}\text { Mittelfranken, Nuernberger } \\
\text { Land, Leinburg, } \\
\text { Wolfsgrube Ost } 405 \mathrm{~m}, \\
\text { 20.vii.2010 }\end{array}$ & A. H. Segerer leg., ZSM & BC ZSM Lep 51392 & BOLD:AAF3597 \\
\hline
\end{tabular}

lems (the first three as limbaria s. 1.). In contrast, the identification of the taxon rablensis is problematic: on the basis of the wing underside (Figs 16, 21) it should belong to limbaria (hindwing with radiating whitish lines), but the upperside (Figs 6,11) of some specimens matches roraria, while that of others matches limbaria (above all in the most western part of its range). According 


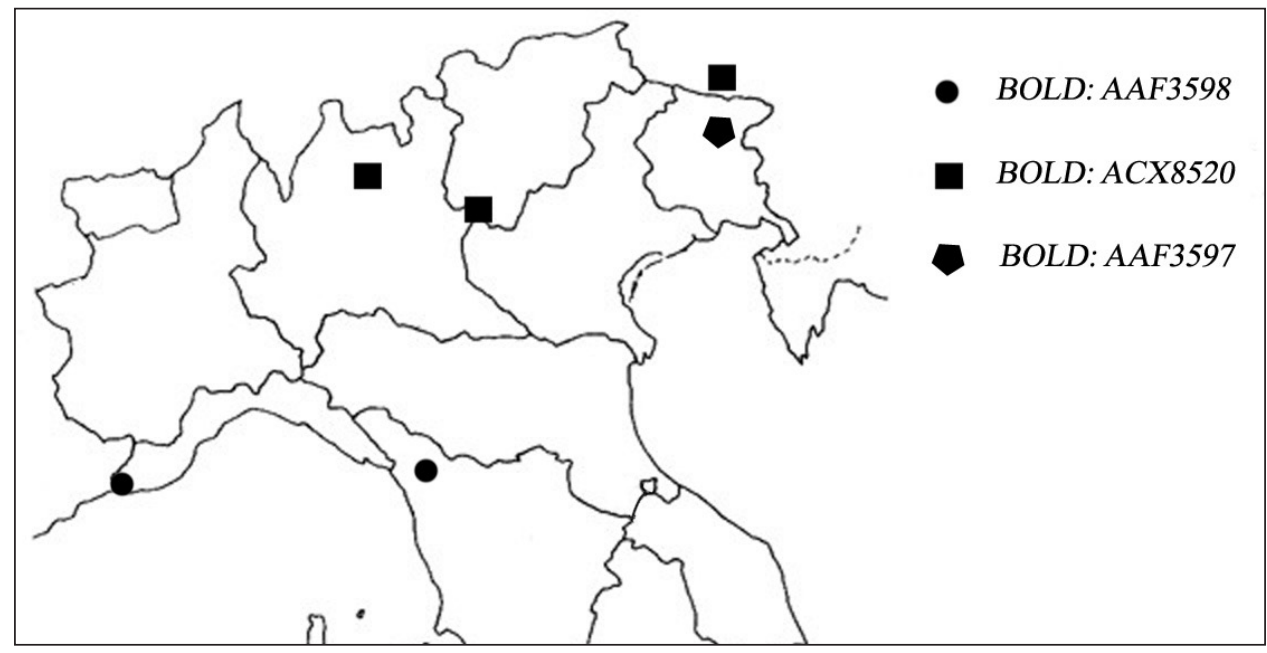

Figure 1. Distribution of the BINs of the complex limbaria/roraria in northern Italy and southern Austria.

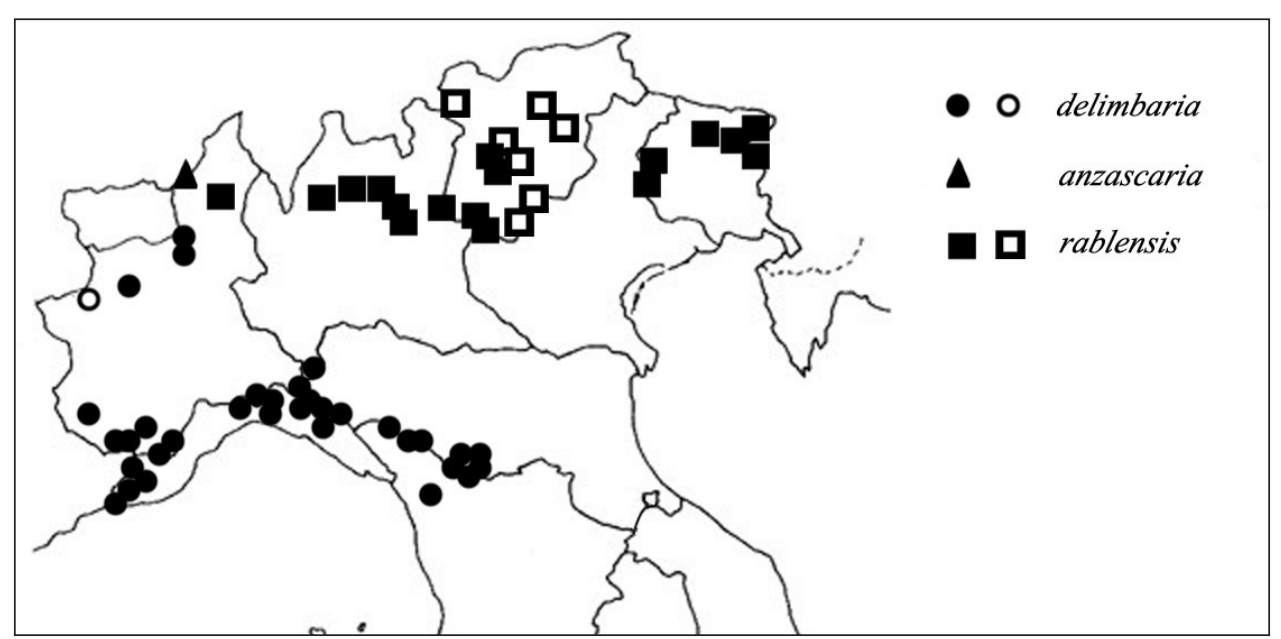

Figure 2. Distribution of the taxa of the complex limbaria/roraria in northern Italy (the open symbols refer to records not verified by the authors).

to Fajčik and Slamka (1996) the width of the dark terminal fascia is also a diagnostic character; wider in roraria (when it is present), narrower in limbaria.

According to Skou and Sihvonen (2015) there are no differences in the male and female genitalia of limbaria and roraria, but in the female of roraria the lamella postvaginalis is often more sclerotized, with the posterior margin round, but they state that these differences are not clear-cut. According to the same authors the bullae tympani have a roundish lobe in limbaria, but not in roraria; however, they suggest that the reliability of this character needs to be tested on more extensive material from the whole distribution range of the complex. 


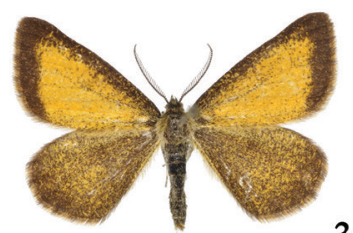

$3 a$

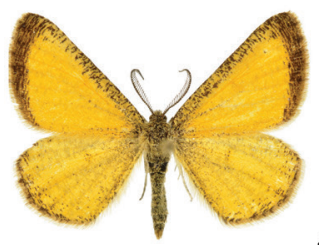

$4 a$

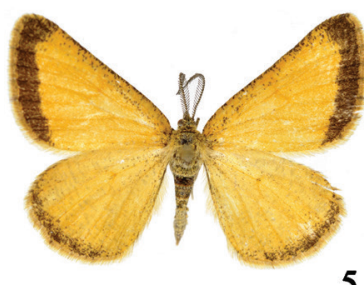

5

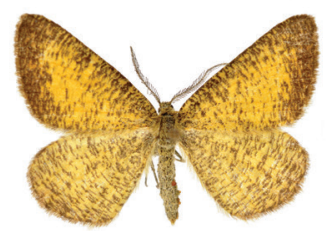

$6 c$

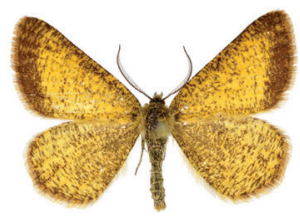

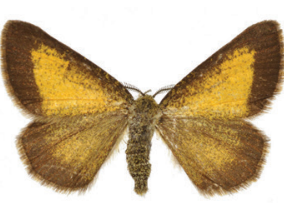

$3 b$

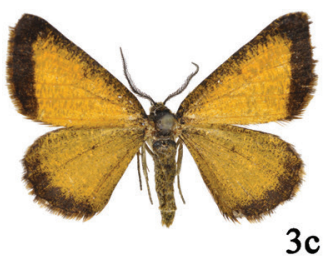

$3 c$

$4 b$

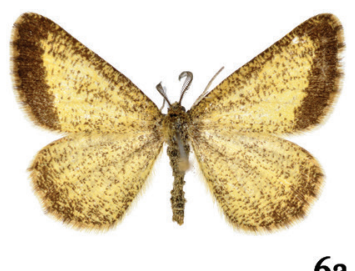

$6 a$

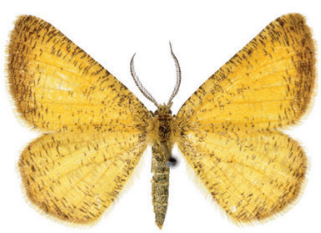

$6 d$

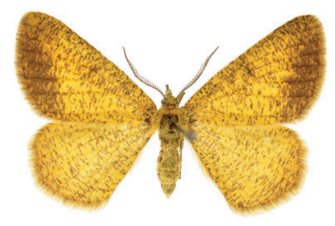

$6 f$

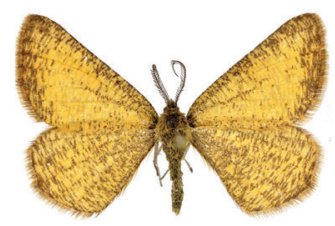

$6 \mathrm{e}$

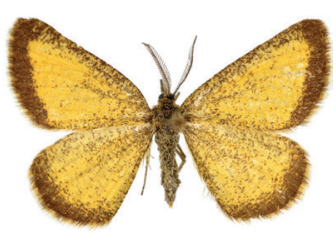

$6 b$

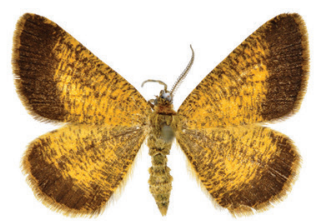

7b

Figures 3-7. Upperside of males (3-7) and females (8-12). 3a. I. l. limbaria $\widehat{\partial}$, Germany: North Rhine-Westphalia, Wuppertal. 3b. I. l. limbaria $\widehat{\partial}$, Switzerland: Valais, district of Sierre, Val d'Anniviers. 3c. I. l. limbaria

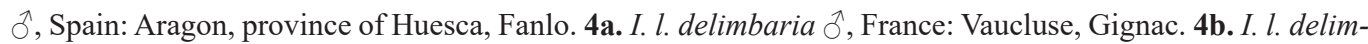
baria f. pedemontaria $\widehat{O}$, Italy: Piedmont, Ligurian Apennines, Capanne Superiori di Marcarolo. 4c. I. l. delimbaria $\widehat{\partial}$, Italy: Emilia-Romagna, Tuscan-Emilian Apennines, Bologna, Monte Pizzo. 5. I. l. anzascaria $\widehat{\jmath}$, Italy: Piedmont, Monte Rosa, Macugnaga, under Alpe Bill. 6a. I. l. rablensis $\widehat{\partial}$, Italy: Piedmont, province of Verbania-Cusio-Ossola, Valstrona, Campello Monti. 6b. I. l. rablensis ふ̃, Italy: Trentino-Alto Adige/Veneto, Monte Baldo, Cima Valdritta. 6c. I. l. rablensis ổ, Italy: Friuli-Venezia Giulia, Carnic Prealps, Barcis, Prescudin. 6d. I. l. rablensis ડ̄, Italy: Friuli-Venezia Giulia, Julian Prealps, Matajur. 6e. I. l. rablensis $\widehat{\partial}$, Macedonia: Baba Planina [Baba Mountain], Pelister, Golemo ezero [Large Lake]. 6f. I. l. rablensis ô, Bulgaria: Sofia, Vitoša [Vitosha]. 7a. I. l. roraria ふૈ, Czech Republic: Moravia, Bílé Karpaty [White Carpathians], Machová. 7b. I. l. roraria $\widehat{\jmath}$, Czech Republic: Moravia, Vápenky. 


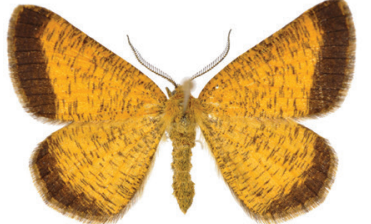

7c

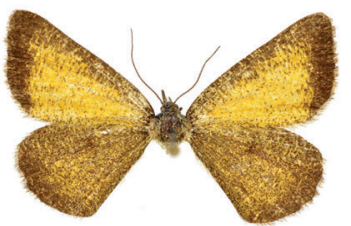

$8 \mathrm{c}$

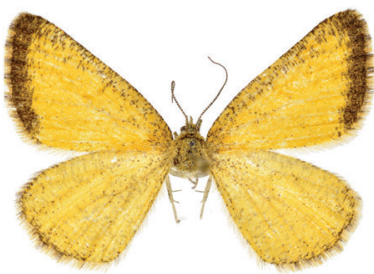

10

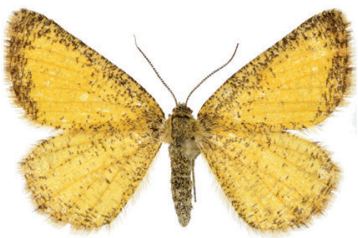

11c

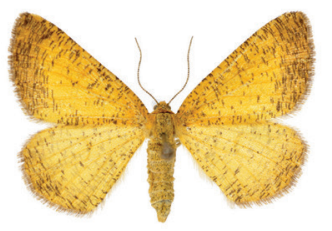

$12 \mathrm{a}$

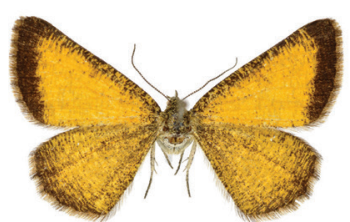

$8 a$

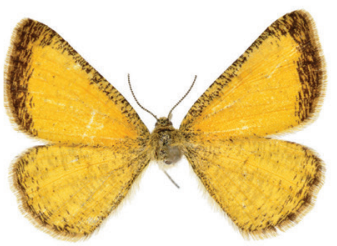

9a

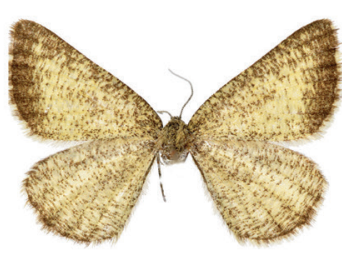

11a

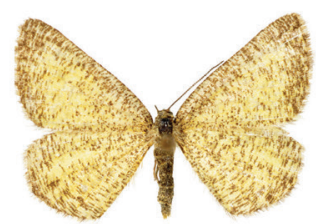

11d

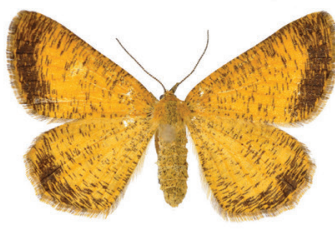

$12 \mathrm{~b}$

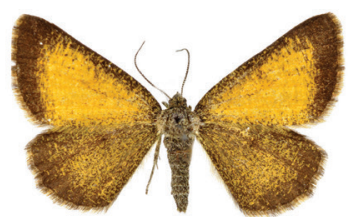

$8 b$
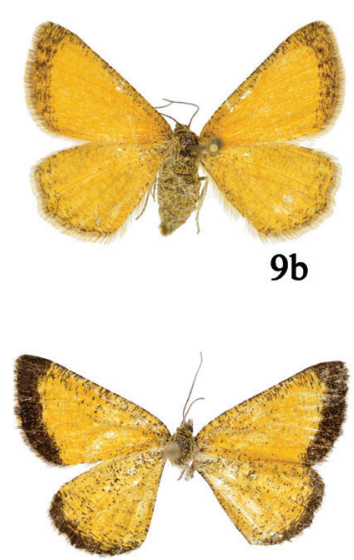

$11 b$

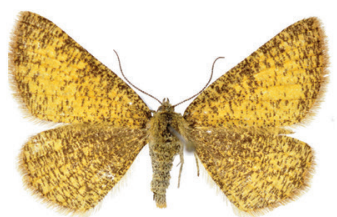

$11 \mathrm{e}$

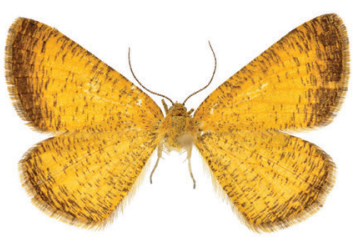

$12 \mathrm{c}$

Figures 7c-12. Upperside of males (3-7) and females (8-12). 7c. I. l. roraria $\hat{O}$, Germany: Bavaria, surroundings of Spalt. 8a. I. l. limbaria ${ }_{+}$, Belgium: Comblain[-au-Pont]. 8b. I. l. limbaria ${ }_{+}$, Switzerland: Valais, district of Sierre, Val d'Anniviers. 8c. I. l. limbaria ${ }_{+}$, Spain: Aragon, province of Huesca, Fanlo. 9a. I. l. delimbaria , France: Alpes-Maritimes, Grasse above Gourdon. 9b. I. l. delimbaria ${ }_{+}$, Italy: Emilia-Romagna, Tuscan-Emilian Apennines, Bologna, Monte Grande. 10. I. l. anzascaria ${ }_{+}$, Italy: Piedmont, Monte Rosa, Macugnaga, under Alpe Bill. 11a. I. l. rablensis $\odot$, Italy: Piedmont, province of Verbania-Cusio-Ossola, Valstrona, Campello Monti. 11b. I. l. rablensis ${ }_{+}$, Italy: Lombardy, Bergamasque Prealps, Camerata Cornello, towards Passo Grialeggio. 11c. I. l. rablensis q, Italy: Trentino-Alto Adige, Brentonico, [Monte Baldo]. 11d. I. l. rablensis + , Italy: Friuli-Venezia Giulia, Julian Alps, Jof Montasio. 11e. I. l. rablensis + , Bulgaria: Sofia, Vitoša [Vitosha]. 12a. I. l. roraria + , Slovakia: Handlová. 12b. I. l. roraria + , Germany: Bavaria, surroundings of Spalt. 12c. I. l. roraria ${ }_{+}$, Germany: Bavaria, Spalt. 


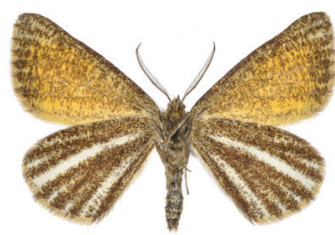

13a

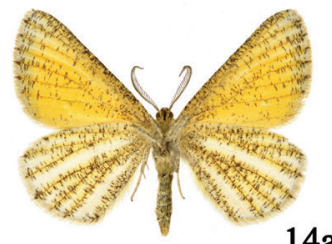

$14 a$

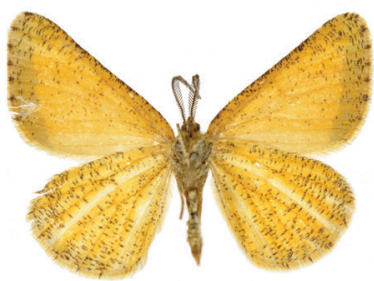

15

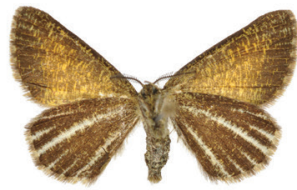

$13 b$

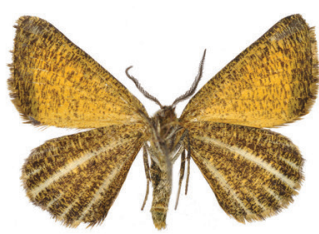

$13 \mathrm{c}$

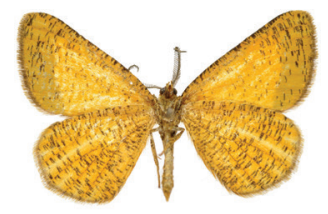

$14 b$

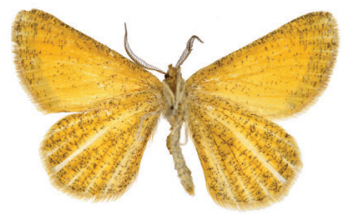

$14 \mathrm{c}$

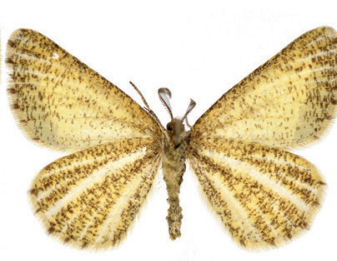

$16 a$

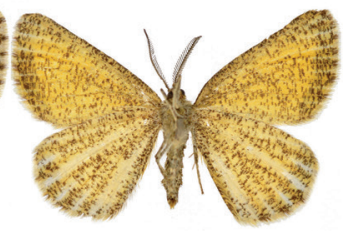

$16 b$

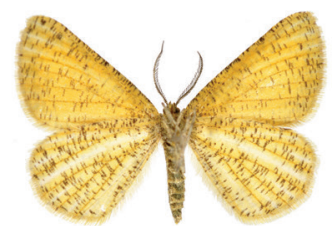

$16 \mathrm{c}$
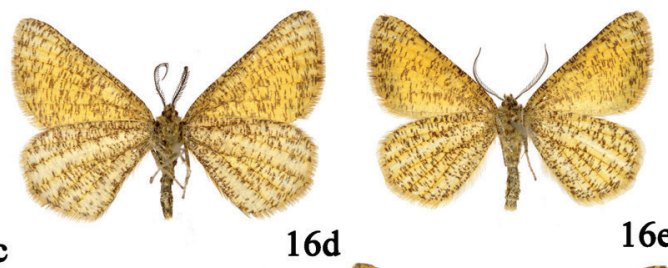

$16 d$
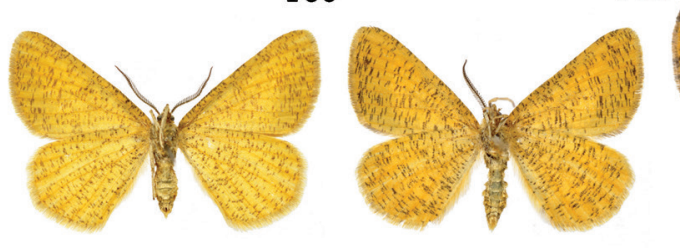

$17 \mathrm{a}$

$17 \mathrm{~b}$

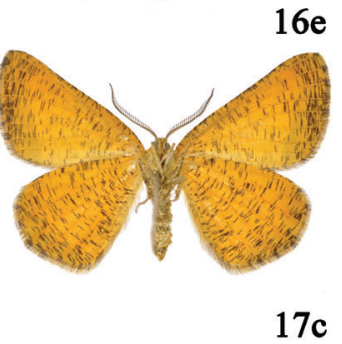

Figures 13-17. Underside of males (13-17). 13a. I. l. limbaria $\widehat{\jmath}$, Germany: North Rhine-Westphalia, Wuppertal. 13b. I. l. limbaria $\widehat{\partial}$, Switzerland: Valais, district of Sierre, Val d'Anniviers. 13c. I. l. limbaria $\widehat{\partial}$, Spain: Aragon, province of Huesca, Fanlo. 14a. I. l. delimbaria Ĵ, France: Vaucluse, Gignac. 14b. I. l. delimbaria f. pedemontaria $\widehat{\partial}$, Italy: Piedmont, Ligurian Apennines, Capanne Superiori di Marcarolo. 14c. I. l. delimbaria $\widehat{\partial}$, Italy: Emilia-Romagna, Tuscan-Emilian Apennines, Bologna, Monte Pizzo. 15. I. l. anzascaria $\widehat{\partial}$, Italy: Piedmont, Monte Rosa, Macugnaga, under Alpe Bill. 16a. I. l. rablensis $\widehat{\partial}$, Italy: Piedmont, province of Verbania-Cusio-Ossola, Valstrona, Campello Monti. 16b. I. l. rablensis $\widehat{\partial}$, Italy: Trentino-Alto Adige/Veneto, Monte Baldo, Cima Valdritta. 16c. I. l. rablensis đ̊, Italy: Friuli-Venezia Giulia, Julian Prealps, Matajur. 16d. I. l. rablensis §̂, Macedonia: Baba Planina [Baba Mountain], Pelister, Golemo ezero [Large Lake]. 16e. I. l. rablensis $\widehat{\jmath}$, Bulgaria: Sofia, Vitoša [Vitosha]. 17a. I. l. roraria ${ }^{\jmath}$, Czech Republic: Moravia, Bílé Karpaty [White Carpathians], Machová. 17b. I. l. roraria đ̊̄, Czech Republic: Moravia, Vápenky. 17c. I. l. roraria $\hat{\partial}$, Germany: Bavaria, surroundings of Spalt 

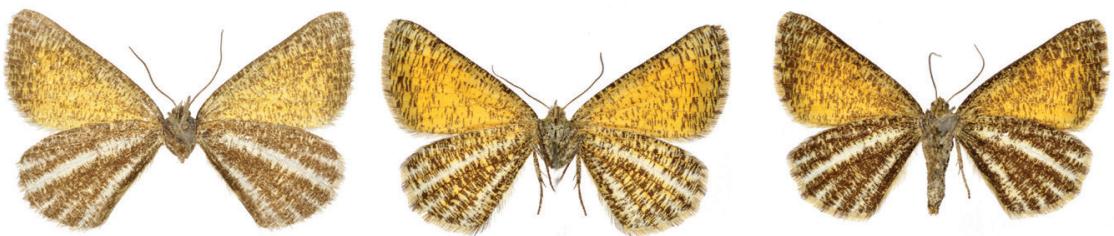

$18 \mathrm{a}$

$18 \mathrm{~b}$

$18 \mathrm{c}$
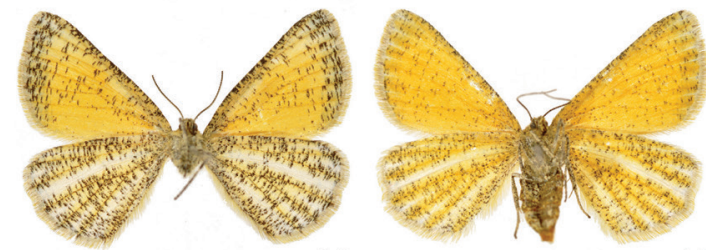

\section{.}

$19 b$
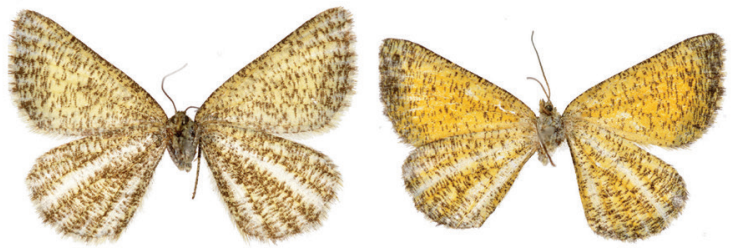

21a

$21 b$
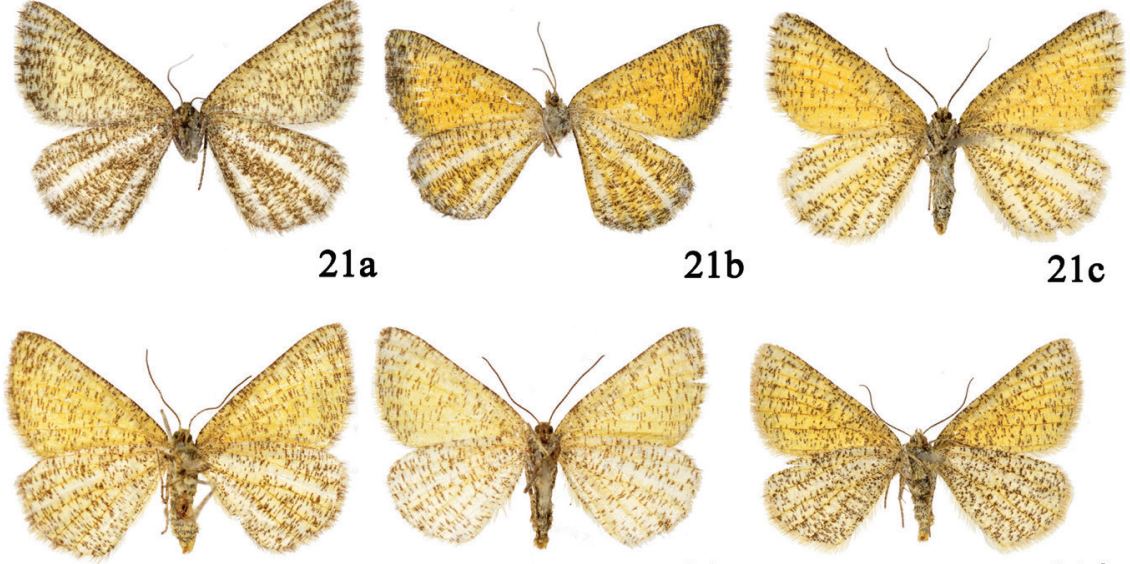

21d

$21 \mathrm{e}$

$21 f$
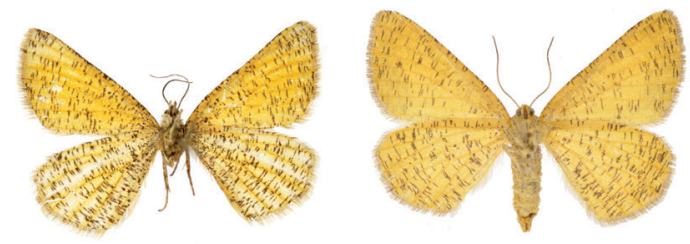

$21 \mathrm{~g}$

$22 a$

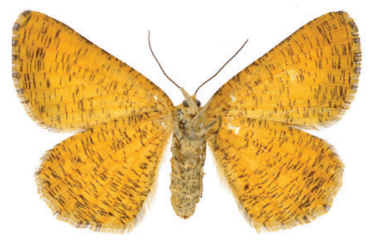

$22 b$

Figures 18-22. Underside of females (18-22). 18a. I. l. limbaria ${ }_{+}$, Belgium: Comblain[-au-Pont]. 18b. I. l. limbaria ${ }_{+}$, Switzerland: Valais, district of Sierre, Val d'Anniviers. 18c. I. l. limbaria ${ }$, Spain: Aragon, province of Huesca, Fanlo. 19a. I. l. delimbaria , France: Alpes-Maritimes, Grasse above Gourdon. 19b. I. l. delimbaria + , Italy: Emilia-Romagna, Tuscan-Emilian Apennines, Bologna, Monte Grande. 20. I. l. anzascaria + , Italy: Piedmont, Monte Rosa, Macugnaga, under Alpe Bill. 21a. I. l. rablensis $\circ$, Italy: Piedmont, province of Verbania-Cusio-Ossola, Valstrona, Campello Monti. 21b. I. l. rablensis $\bigcirc$, Italy: Lombardy, Bergamasque Prealps, Camerata Cornello, towards Passo Grialeggio. 21c. I. l. rablensis Adige, Brentonico, [Monte Baldo]. 21d. I. l. rablensis ${ }_{+}$, Italy: Friuli-Venezia Giulia, Carnic Prealps, Barcis, Prescudin. 21e. I. l. rablensis +, Italy: Friuli-Venezia Giulia, Julian Alps, Jof Montasio. 21f. I. l. rablensis + , Bulgaria: Sofia, Vitoša [Vitosha]. 21g. I. l. rablensis ${ }_{+}$, Bulgaria: Sofia, Vitoscha [Vitosha]. 22a. I. l. roraria †, Slovakia: Handlová. 22b. I. l. roraria + , Germany: Bavaria, surroundings of Spalt. 
J. Gelbrecht (pers. comm.) found differences in the size of the signum in the female genitalia.

The morphological characters observed in the material examined by us are summarized in Table 3 (further information in the treatment of single taxa in the section Taxonomy). Some examples of variability of the lamella postvaginalis, of the tympanic organs and of the signum are illustrated respectively in Figures 23-34.

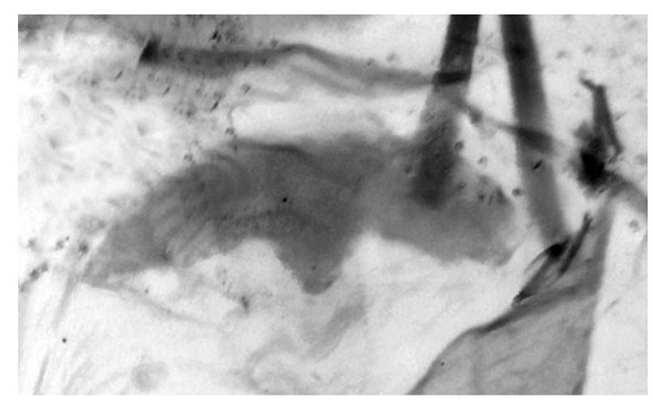

23

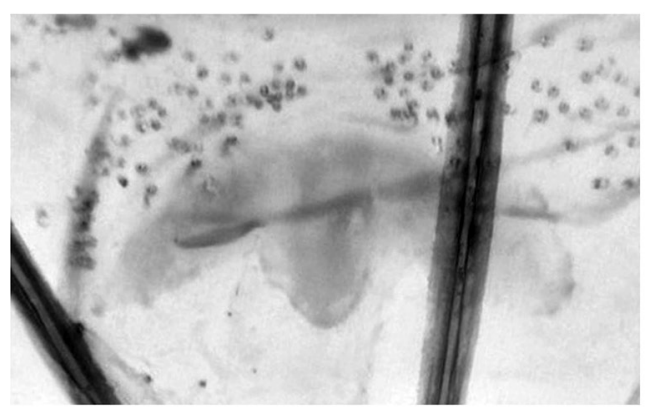

$24 b$

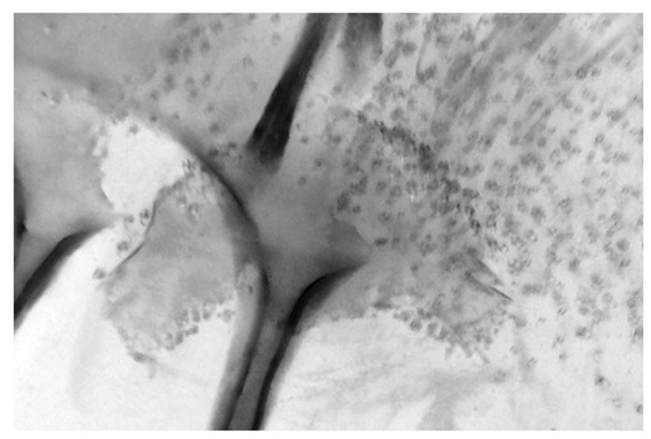

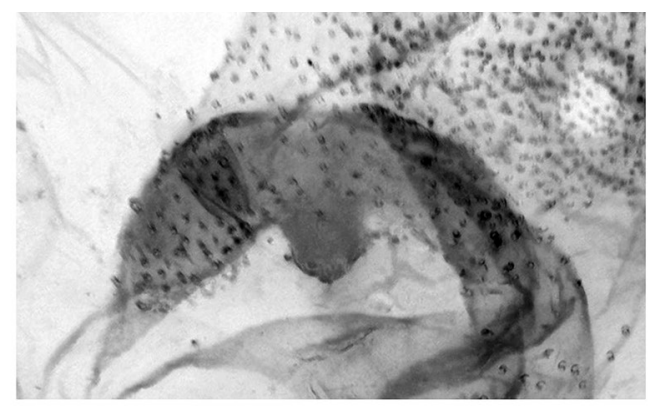

$24 a$

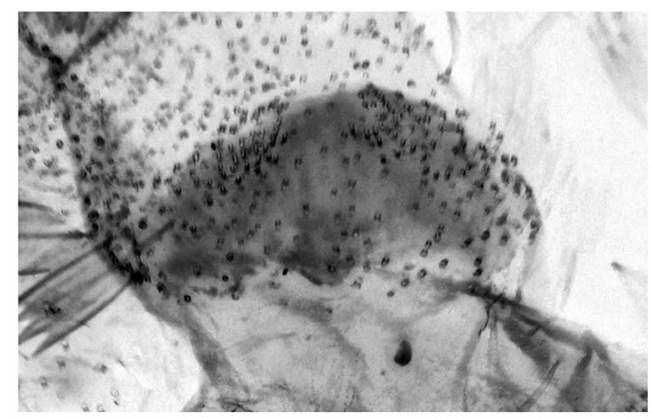

25

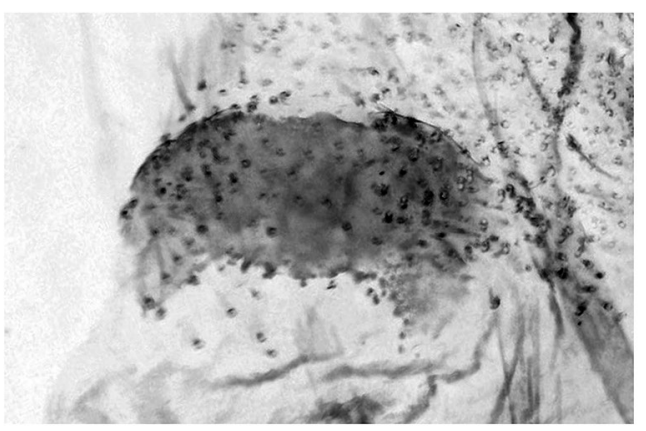

Figures 23-27. Variability of the lamella postvaginalis. 23. I. l. limbaria, Belgium: Comblain[-au-Pont]. 24a. I. l. delimbaria, Italy: Liguria, Ligurian Alps, Rocchetta Nervina, Passo del Cane. 24b. I. l. delimbaria, Italy: Emilia-Romagna, Tuscan-Emilian Apennines, Bologna, Bologna, Corno alle Scale, Passo del Vallone. 25. I. l. anzascaria, Italy: Piedmont, Monte Rosa, Macugnaga, under Alpe Bill. 26. I. l. rablensis, Bulgaria: Sofia, Vitoscha [Vitosha]. 27. I. l. roraria, Germany: Bavaria, Spalt. 


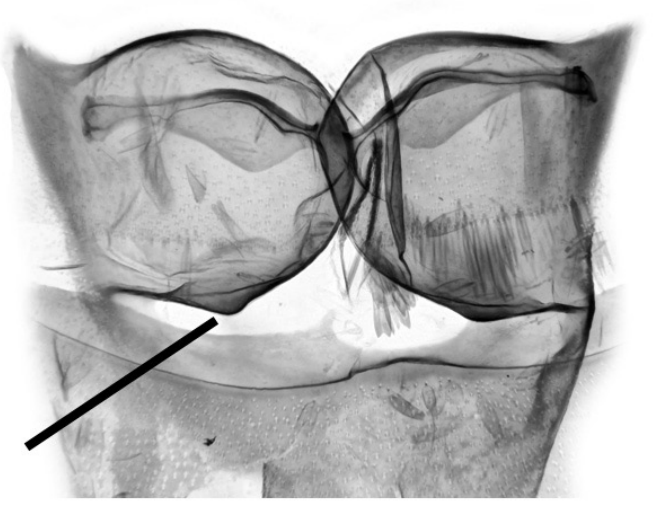

$28 \mathrm{a}$

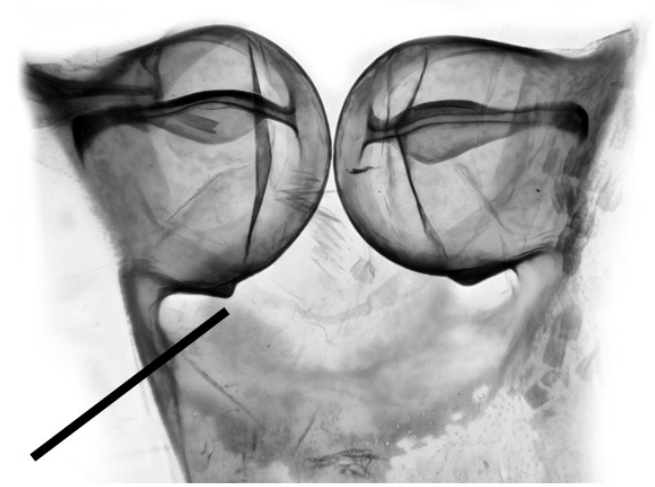

$28 b$

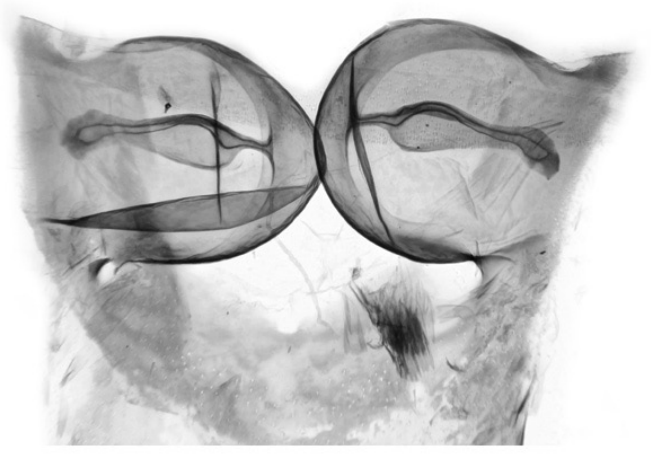

$28 \mathrm{c}$

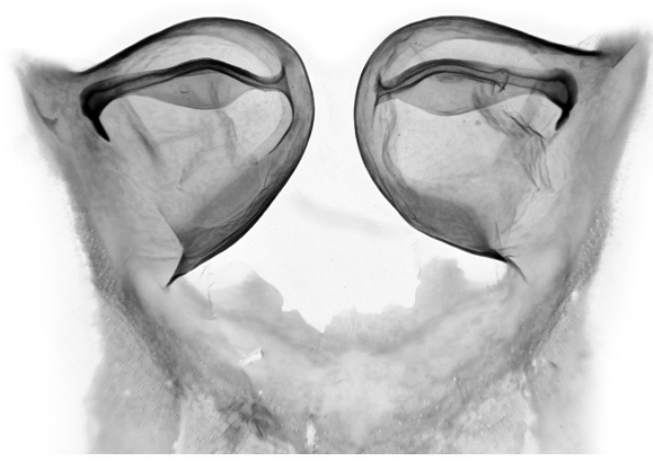

29

Figures 28, 29. Variability of the bullae tympani (bars point at the rounded lobes). 28a. I. l. delimbaria ${ }_{+}$, France: Alpes-Maritimes, Grasse above Gourdon. 28b. I. l. delimbaria $\odot$, Italy: Liguria, Ligurian Apennines, Maissana, road to Passo del Bocco di Bargone. 28c. I. l. delimbaria +, Italy: Emilia-Romagna, Tuscan-Emilian Apennines, Bologna, Bologna, Corno alle Scale, Passo del Vallone. 29. I. l. rablensis + , Italy: Piedmont, province of Verbania-Cusio-Ossola, Valstrona, Campello Monti.

Our observations confirm that the posterior margin of the lamella postvaginalis is often more curved in roraria and rablensis than in limbaria, but this character is variable, especially in the Italian populations, and it does not allow to identify the various taxa with certainty.

\section{Preimaginal stages}

J. Gelbrecht (pers. comm.) has bred material of the taxa limbaria s. str. (from Lüneburg Heath in Lower Saxony, Germany), delimbaria (from southern France), rablensis (from Vitosha, Bulgaria) and roraria s. str. (from Dessau in Saxony-Anhalt, Germany). Based on his observation, the larvae of limbaria and delimbaria are identical, darker green than roraria and rablensis, with brownish markings, the head capsule is more marked with black than in roraria and rablensis; the larvae of roraria and rablensis are mostly completely green, rarely with a brownish ground colour (in 
Table 3. Analysis of the morphological characters observed in the material examined.

\begin{tabular}{|c|c|c|c|}
\hline Taxon & \multirow[t]{2}{*}{ Upperside } & \multirow[t]{2}{*}{ Underside } & \multirow{2}{*}{$\begin{array}{c}\text { Female genitalia and tympanal } \\
\text { organs }\end{array}$} \\
\hline $\begin{array}{c}\text { BIN } \\
\text { place of origin of the material }\end{array}$ & & & \\
\hline limbaria s. str. & $\begin{array}{l}\left(\jmath^{\wedge}\right) \text { Forewing more or less } \\
\text { irrorated with brown scales }\end{array}$ & $\begin{array}{l}\text { (of) Forewing scattered with } \\
\text { dark vertical stripes or more }\end{array}$ & $\begin{array}{l}\text { Signum: } 0.7-1 \mathrm{~mm}(\mathrm{n}=2, \text { from } \\
\text { Spain and Belgium). }\end{array}$ \\
\hline
\end{tabular}

BOLD:AAF3598

Spain, Belgium, Germany (North Rhine-Westphalia), Switzerland

\section{BOLD:AAF3598}

France SE, Italy (Ligurian Alps, Northern Apennines)

delimbaria (sometimes almost absent except in the costa and in the terminal fascia). Width of the forewing dark terminal fascia about 2 $\mathrm{mm}$ (rarely $1 \mathrm{~mm}$ ), hindwing dark terminal fascia generally well developed, rarely reduced; hindwing often densely covered with dark scales.

\begin{tabular}{l|l} 
& \multirow{2}{*}{} \\
\hline anzascaria & $(10)$ Forewing almost free of
\end{tabular}

not barcoded

Italy (northern Piedmont:

Macugnaga)

\section{dark scales (except the costa and} the terminal fascia). Hindwing with a few dark scales. Width of the forewing dark terminal fascia $1.5-2 \mathrm{~mm}$, hindwing dark terminal fascia narrow or reduced to a few scales.

rablensis

BOLD:ACX8520

Italy (northeastern Piedmont, Lombardy, Monte Baldo)

\section{rablensis}

BOLD:AAF3597

Julian Alps (Italy and Slovenia)

rablensis

not barcoded

(most likely BOLD:AAF3597)

Macedonia (ð⿱中) Forewing often with only a few dark scales (except the costa and the terminal fascia), a little more dense in the hindwing; sometimes both wings scattered with dense groups (or short stripes) of dark scales. Width of the dark terminal fascia generally just over $1 \mathrm{~mm}$.

(ðㅇ) Wings scattered with sparse groups (or short stripes) of dark scales, sometimes with more dense dark vertical stripes. Width of the dark terminal fascia just over $1 \mathrm{~mm}$.

(ठ) Forewing scattered with sparse groups (or short stripes) of dark scales, hindwing with dense dark vertical stripes. Width of the dark terminal fascia just over $1 \mathrm{~mm}$.

\section{densely sprinkled with dark}

scales. Hind wing more or less

densely covered with dark scales, except the whitish radiating streaks.
Bullae tympani with a roundish

lobe (visible only in one bulla in a female from Spain). $\left(\delta^{\wedge}+\right)$ Hindwing scattered with dark vertical stripes (much less numerous on the fore wing).

Whitish radiating streaks of the hindwing present.

\section{$(\jmath+$ ) Fore- and hindwing} scattered with dark vertical stripes (more dense on the hindwings); ground colour of forewing more orange than the hindwing. Whitish radiating streaks of the hindwing present. ( $\lesssim$ ) Fore and hindwing scattered with dense dark vertical stripes; ground colour of forewing more orange. Whitish radiating streak of the hindwing present. (altogether in the taxon rablensis)

Signum: $1.1 \mathrm{~mm}$ (exceptionally

$1.6 \mathrm{~mm}$ in a female from

Lombardy) ( $\mathrm{n}=6$, from northeastern Piedmont, Lombardy, Monte Baldo, Carnic Prealps, Italian Julian Alps and Bulgaria). Bullae tympani without roundish lobe. 


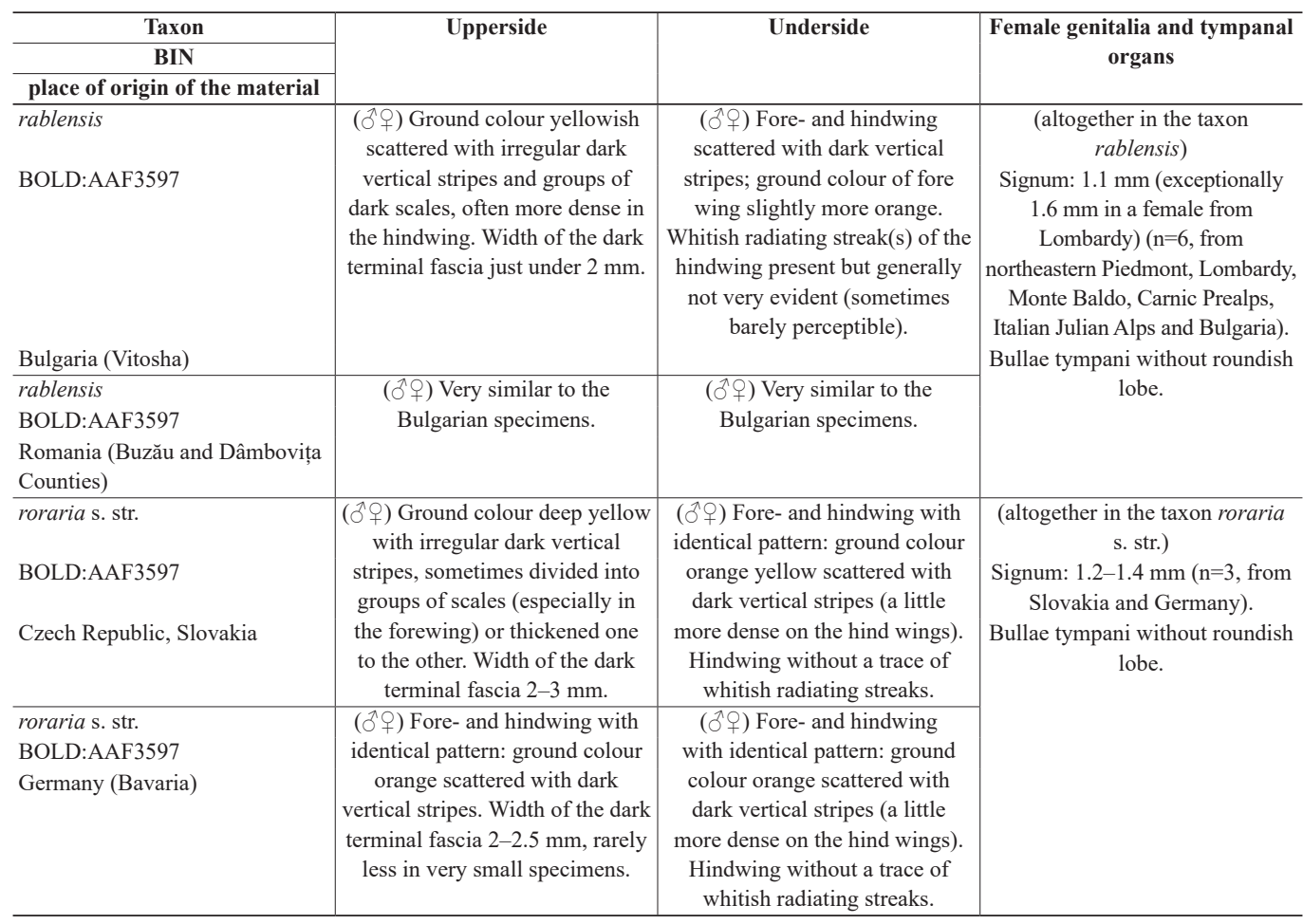

rablensis), the markings of the head capsule are weak. The shape of the pupal cremaster of delimbaria is similar to limbaria (thinner and a little longer), that of rablensis is similar to roraria (shorter and thicker) (Figs 35-38). Buckler (1897) shows green and brown larvae, both from Great Britain (taxon limbaria s. str.). The morphology of the larval and pupal stages of roraria s. str. is described and illustrated in detail by Blaik and Malkiewicz (2003) (material from south-western Poland): their images of the cremaster match rather well those of Gelbrecht, but not those of Patočka (1986) (from Slovakia, as I. limbaria roraria). Images of the preimaginal stages of the complex limbaria/roraria can also be found on the web: larvae from Netherlands (UKmoths 2019), France (Mazzei et al. 2019: Ariège; Lepi'Net 2019: Lot), eggs, larvae and pupae from Germany (Lepiforum 2019: limbaria from Rhineland-Palatinate, roraria from Saxony-Anhalt).

Gelbrecht also did breeding experiments (pers. comm.). The taxa limbaria and delimbaria crossbred easily; he managed to rear some adults also from the crossing between rablensis (from Bulgaria) and roraria. In laboratory conditions he also obtained a pairing between delimbaria and rablensis: the few eggs hatched but the larvae died immediately.

We have not found any images of the preimaginal stages of the Italian populations and we do not believe that breeding experiments have ever been carried out between them.

\section{Discussion and conclusions}

Populations delineated on the basis of molecular data, the size of the signum and the presence (or absence) of a roundish lobe in the bullae tympani, can be divided into two groups: one including 

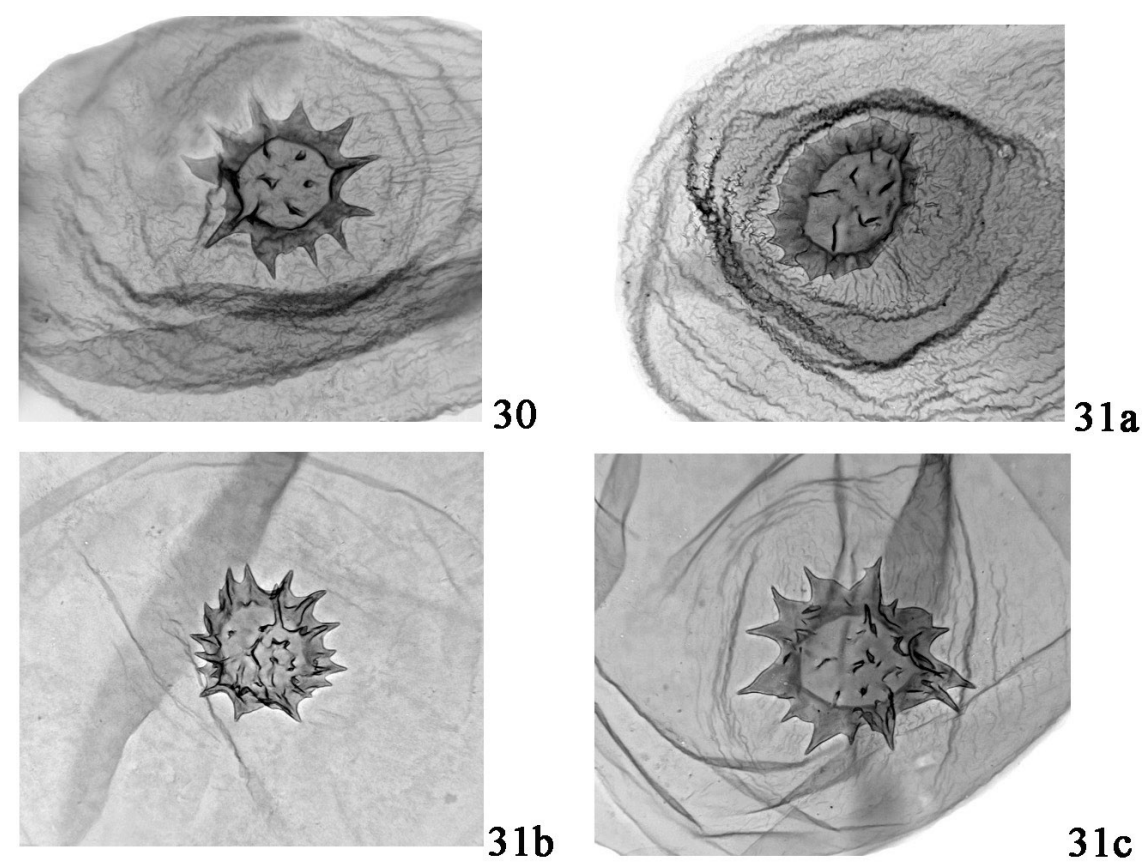

$31 \mathrm{c}$
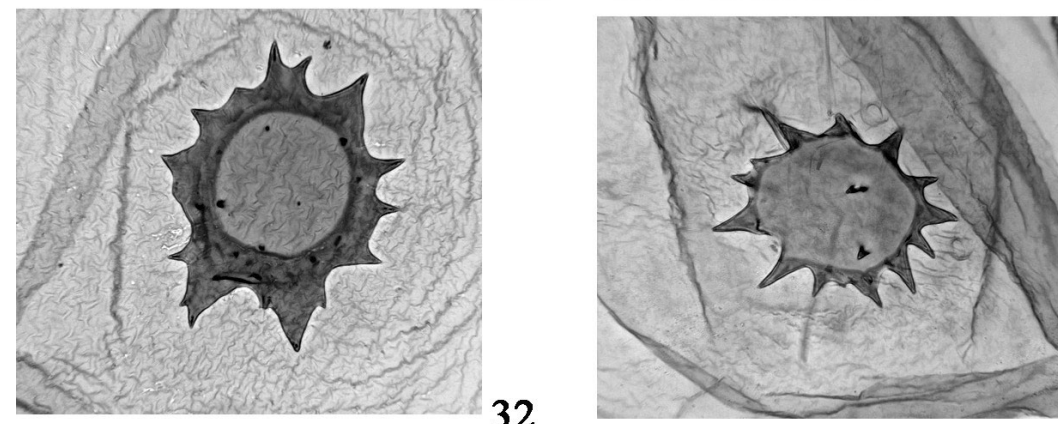

32
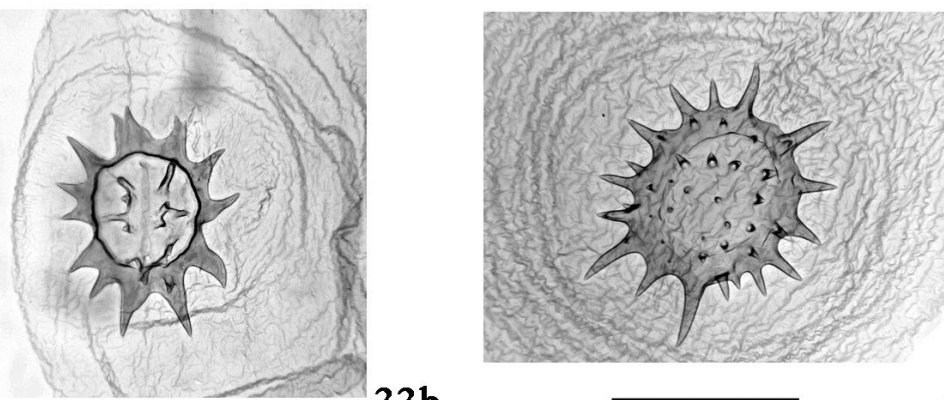

$33 b$

\section{$1 \mathrm{~mm}$}

$33 a$

Figures 30-34. Variability of the signum. 30. I. l. limbaria, Belgium: Comblain[-au-Pont]. 31a. I. l. delimbaria, France: Alpes-Maritimes, Grasse above Gourdon. 31b. I. l. delimbaria, Italy: Emilia-Romagna, Tuscan-Emilian Apennines, Bologna, Bologna, Corno alle Scale, Passo del Vallone. 31c. Italy: Emilia-Romagna, Tuscan-Emilian Apennines, Bologna, Bologna, Corno alle Scale. 32. I. l. anzascaria, Italy: Piedmont, Monte Rosa, Macugnaga, under Alpe Bill. 33a. I. l. rablensis, Italy: Veneto, Monte Baldo, Bocca di Navene. 33b. I. l. rablensis, Bulgaria: Sofia, Vitoscha [Vitosha]. 34. I. l. roraria, Germany: Bavaria, Spalt. 


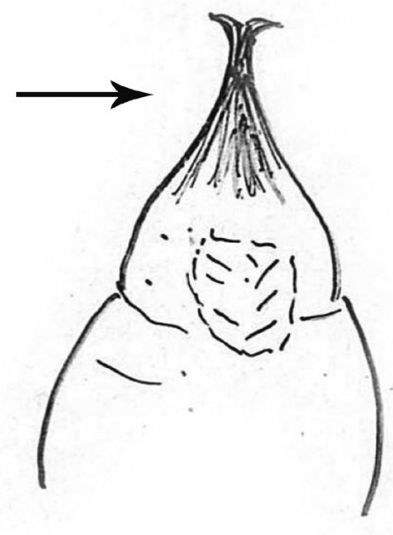

35

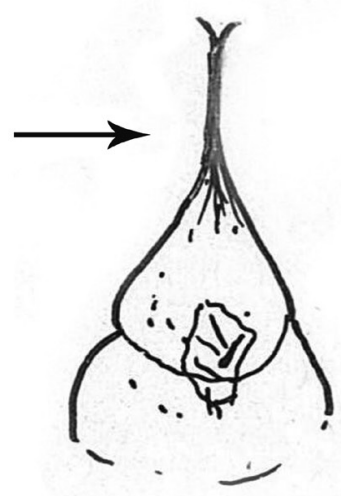

37

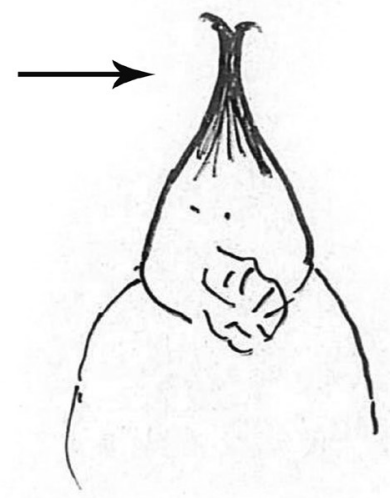

36

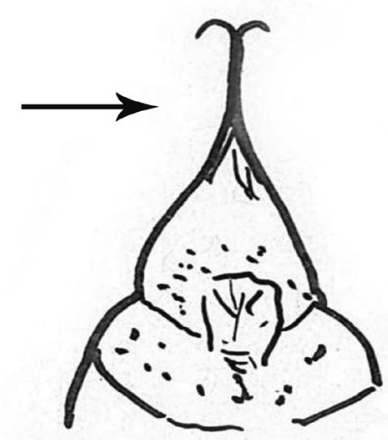

38

Figures 35-38. Pupal cremaster (drawings by J. Gelbrecht). 35. I. l. rablensis, Bulgaria: Sofia, Vitosha. 36. I. l. roraria, Germany: Saxony-Anhalt, Dessau. 37. I. l. delimbaria, southern France. 38. I. l. limbaria, Germany: Lower Saxony, Lüneburg Heath.

the taxa limbaria s. str. and delimbaria, and the other the taxa roraria s. str. and rablensis. The taxon anzascaria (not yet barcoded) can also be attributed to the latter group as it shares with rablensis and roraria a larger signum (see Table 3 ) and the absence of a roundish lobe in the bullae tympani; most of the populations of rablensis (from the Julian Alps to Romania) share the same BIN with roraria, while the most western ones (northern Italy, excluding the Julian Alps, and southern Austria) share their own barcode cluster which is much closer to roraria than to delimbaria and limbaria s. str.. This population is, however, not morphologically distinguishable from that from the Julian Alps. However, the diagnostic wing pattern characters until now used to identify the two species 
limbaria and roraria do not correlate with these two groups: the taxa rablensis and anzascaria are more similar to limbaria in the hindwing underside (whitish radiating streaks present); the pattern of the upperside wing is variable and often intermediate between limbaria and roraria in rablensis (especially in the Italian populations), while in anzascaria it is rather similar to delimbaria (forewing upperside almost free of dark scales, except the costa and the terminal fascia).

Furthermore, the two groups of populations are not completely separated from each other. Some populations of the northern Apennines (taxon delimbaria) cannot be clearly attributed to one or the other group: a barcoded specimen from the "Apuan Alps" in Tuscany (northern Apennines) shares the same BIN with delimbaria and limbaria s. str. (diverging by $1.6 \%$ from both the cluster of limbaria s. str. and the specimen of delimbaria from the Ligurian Alps). However, in the Apennines near Bologna there are females with a large signum (as in roraria s. str. and rablensis) and females with a small signum; in the latter area a female lacks the roundish lobes in the bullae tympani (like in roraria s. str. and rablensis), in the single male examined they are barely visible.

The genetic distance between the two groups of populations of the I. limbaria/roraria complex is considerable. However, the correlation between molecular differences and morphological characters is not completely constant, as shown by the example of the Apennine populations just mentioned. In the absence of constant morphological characters associated with the molecular differences and in the presence of Italian populations with intermediate characters, we believe it better, in the current state of knowledge, to consider the different taxa of this complex as subspecies of the same species, as already proposed by Povolný and Moucha $(1957,1959)$. However, the available data do not allow a definitive clarification of the taxonomic problem and further research is necessary to consider the conspecificity of the clusters of the different taxa. Additional genetic data are necessary (in particular from northern Piedmont and the Apennines), as well as an in-depth study of the preimaginal stages of the Italian populations, with breeding experiments between them to check their interfertility.

Gelbrecht's breeding experiments suggest the conspecificity between limbaria s. str. and delimbaria on the one hand and between rablensis (from Bulgaria) and roraria s. str. on the other. However, they do not exclude the possible interfertility between Italian populations belonging to different taxa: other experiments would be necessary for this purpose. Also the immutability of differences in the larva and in the pupal cremaster should be confirmed through the study of the Italian populations.

These results emphasize the need to further investigate the patterns of mitochondrial DNA in "hybrid" populations. In our research on Ennominae (cf. Flamigni et al. 2016) we have met other cases of mismatch between DNA barcodes and morphological characters: specimens from southern Piedmont (north-western Italy) are closer to the genetic cluster of Yezognophos serotinaria serotinaria (Denis \& Schiffermüller, 1775) even though their genitalia are similar to those of $Y$. serotinaria serotinoides (Wehrli, 1922); in addition, in the northern Apennines the male genitalia and sometimes also the female ones, although clearly attributable to the "western" taxon serotinoides, show some elements of transition towards the "eastern" nominate serotinaria, showing a parallelism with the above comments on the taxa delimbaria and rablensis. The taxon Psodos chalybaeus Zerny, 1916 (valid at subspecies rank according to Flamigni et al. (2016), downgraded to a synonym of Psodos alticolaria alticolaria Mann, 1853 by Müller et al. (2019), but with the need for further investigations) occurs in a well defined area of the Rhaetian Alps, with a different BIN and a characteristic wing pattern; however, specimens collected in the surroundings of Obergurgl (Austria: North Tyrol) in two very close localities are very similar to each other in wing 
pattern (intermediate between alticolaria alticolaria and chalybaeus), but they have two different BINs (corresponding to those of these two taxa). The specimens of Hylaea Hübner, 1822, from Molise (central Italy) are often more similar in wing pattern to $H$. fasciaria (Linnaeus, 1758) (with minimal differences in variable female genitalia), but they share the same BIN as $H$. mediterranea Sihvonen, Skou, Flamigni, Fiumi \& Hausmann, 2014. Also the status of subspecies could be a possible alternative for the taxon mediterranea.

\section{Summary}

Our findings indicate that the relation of barcodes to morphology is a complicated issue, and a 'correct' taxonomic interpretation may be impossible to reach solely with these approaches. The case of Isturgia taxonomy is an illustrative example of a complicated taxonomic pattern that we observe, potentially showing an example of the current situation resulting from an historical biogeographical pattern initiated during the glaciation eras of Europe.

\section{Taxonomy}

\section{Isturgia limbaria limbaria (Fabricius, 1775)}

Phalaena limbaria Fabricius, 1775, Syst. Ent. 624, Anglia [England].

Geometra conspicuata [Denis \& Schiffermüller], 1775, Ankündung syst. Werkes Schmett. Wienergegend: 316, [Germany, Hesse: Frankfurt am Main]. Syntype(s) from the collection Gerning (Frankfurt a. M., 1745-1802). The taxon limbaria s. str. is not recorded from Vienna; in Lower Austria and in neighbouring Moravia only the taxon roraria occurs.

Ph[alaena] Geom[etra] auroraria Hübner, [1787], Beitr. Gesch. Schmett. 1 (2): 27, pl. 4, fig. Y, 1, 2. According to Scoble (1999) it is a synonym both of limbaria and roraria: Hübner's figures clearly show that it is limbaria.

Phal[aena] Geom[etra] circumdataria Villers, 1789, Linn. ent. 2: 330, pl. 6, fig. 10, Europe, Gallia [France].

Phalaena Geometra conspicuaria Borkhausen, 1794, Natur. eur. Schmett. 5: 465, Europe.

Geometra spartariaria Hübner, [1799], Samml. Eur. Schmett. 5 Geometrae (1): pl. 22, fig. 116, Europe.

Ph[alaena] Geom[etra] conspicuaria Esper, [1801], Die Schmett. 5 (5): 124, pl. 24, figs 5-7, Syntype(s), [Germany, Hesse]: Frankfurt am Main, Darmstadt; Switzerland; Hungary [patria falsa?]. Junior primary homonym of conspicuaria Borkhausen, 1794. Synonym of roraria according to Scoble (1999) and Skou and Sihvonen (2015); the syntypes were identified by Hacker (1999) as I. limbaria limbaria; the same author designated as paralectotype a male from the Esper collection (ZSM Munich) and as lectotype one from the Gerning collection (LMW Wiesbaden). In Hungary only the taxon roraria occurs.

Fidonia limbaria ab. quadripunctaria Fuchs, 1899, Jb. nassau. Ver. Naturk. 52: 150, [Germany], [Rhineland-Palatinate]: Loreley district [infrasubspecific: each wing with black discal spot].

Fidonia conspicuata ab. fumata Mathew, 1907, Entomologist's Rec. J. Var. 19: 21, [England]: Suffolk [infrasubspecific].

Fidonia limbaria ab. nigricaria Bubacek, 1915, Verh. zool.-bot. Ges. Wien 65: (109), [France], Pyrénées-Orientales: surroundings of Vernet-les-Bains $2200 \mathrm{~m}$ [infrasubspecific].

Fidonia limbaria var. infuscata Thierry-Mieg, 1916, Miscnea. ent. 23: 50, Europe [infrasubspecific].

Fidonia limbaria f. nigrostriata Heydemann, 1938, syn. n., Ent. Z. Frankf. a. M. 52 (3): 23, pl. 1, figs 21, 22, [Germany]: southern Holstein [infrasubspecific]. Valid at subspecies rank according to Scoble (1999); however, according to the original description it co-exists with f. quadripunctaria ["it appears here in a percentage up to almost $45 \%$ among the quadripunctaria Fuchs"]; also Lempke (1952) considers it an individual form, frequent in the Netherlands.

Isturgia limbaria f. postnigrescens Lempke, 1952, Tijdschr. Ent. 95: 208, Netherlands: Harendermolen, Nijmegen, Roermond, Steenwijk, Winterswijk, Montferland, Veenendaal [infrasubspecific: "hind wings unicolorous blackish"].

Isturgia limbaria f. postclara Lempke, 1952, Tijdschr. Ent. 95: 208, Netherlands: Wehl, Tilburg [infrasubspecific: "hind wings as clear as the fore wings"].

Isturgia limbaria f. postdemarginata Lempke, 1952, Tijdschr. Ent. 95: 208, Netherlands: Roermond [infrasubspecific: "hind wings without the dark marginal band"].

Material examined. Spain: $1 \hat{\jmath}, 1$ \&, Aragon: province of Huesca, Fanlo, 1.vi.2007, Perez leg. (RCCF). Belgium: $1 \hat{\jmath}$, 1 q, Comblain[-au-Pont], 14.v.2000, Evrard leg. (RCCF). Germany: 1 ô, 1 , North Rhine-Westphalia: Wuppertal 
12.v.2006, Hager leg. (RCCF); 1 §, Thuringia: Treffurt, Eichsfeld, ex 1. 12.ix.1992/2.iii.1993, E. Friedrich leg. (RCEF) (digital images of both sides on Lepiforum). Switzerland: 1 ^, 1 ㅇ, Valais: district of Sierre, Val d'Anniviers, 1.vii.2005, Chapelle leg., (RCCF).

Colour images of specimens from Great Britain are shown in Ford (1972: pl. 29, figs 13-15): from Ipswich in England (upperside and underside) and from Achanalt in Scotland (upperside).

Diagnosis (Figs 3, 8, 13, 18). Dark terminal fascia almost always well developed on the four wings. Hindwing often densely covered with dark scales, sometimes unicolorous blackish. Hindwing underside more or less densely covered with dark scales, except the whitish radiating streaks.

In the female genitalia signum small $(0.7-1 \mathrm{~mm})$. Bullae tympani with a roundish lobe (visible only in one bulla in a female from Spain).

Distribution. Great Britain (Scotland and eastern England, now extinct), part of Germany (cf. Skou and Sihvonen 2015: map on page 97), Benelux, France (excluding the southern Alps), northern Spain (eastern Aragonese, Andorran and Catalan Pyrenees). Our specimens from Valais confirm the occurrence of the species in Switzerland, where only old records existed (cf. Reser 2010).

Remarks. According to Skinner (1984) the specimens from Ross-shire (Scotland) are larger and paler than those from southern England; the difference is also evident in the images in Ford (1972).

\section{Isturgia limbaria delimbaria (Staudinger, 1892)}

Fidonia limbaria var. delimbaria Staudinger, 1892, Dt. ent. Z. Iris 5: 198, [France]: Basses Alpes [Alpes-de-HauteProvence], near Castellane and Digne.

Fidonia limbaria var. pedemontaria Staudinger, 1892, Dt. ent. Z. Iris 5: 198, [France]: Alpes-Maritimes, [Italy]: Piedmont. Synonymy according to Flamigni et al. (2007, 2016).

Fidonia limbaria var. ligurica Fuchs, 1899, Jb. nassau. Ver. Naturk. 52: 151, [Italy]: Liguria. Synonym of pedemontaria according to Wehrli (1940).

Material examined. France: $1 \hat{\jmath}$, Vaucluse: Gignac, 21.iv.1979, F. Coenen leg. (RCCM); $1 \hat{\partial}$, Alpes-Maritimes: Gréolières 950 m, 21.iv.1997, G. Govi leg. (RCGG); 1 †, Alpes-Maritimes: Grasse above Gourdon, 750 m, 4.v.1998, G. Govi leg. (RCGG); 1 §̊, 1 \&, Alpes-de-Haute-Provence: St-Étienne-les-Orgues, Montagne de Lure, 1620 m, 24.v.2014, E. Friedrich

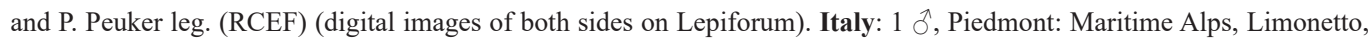
1000 m, 24.v.1998, G. Fiumi leg. (RCGF); 1 ふै, Piedmont: Ligurian Alps, Piaggia, 1300 m, 29.vi.1986, G. Bastia leg.

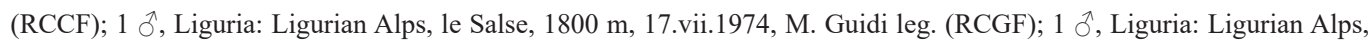
Ventimiglia, Villatella, Monte Grammondo, 1150 m, 9.v.2015, M. Guaschino leg. (RCCM); 1 ふै, Liguria: Ligurian Alps, Ventimiglia, 600 m, 27.v.2001, E.O. Bonora leg. (RCCM); 4 ふै, 2 ㅇ, Liguria: Ligurian Alps, Rocchetta Nervina, Passo del Cane, 600 m, 23.v.1998, G. Fiumi leg. (RCGF); 1 \%, Liguria: Ligurian Alps, Cosio di Arroscia, 1000 m, E.O. Bonora leg., 4.v.2006 (RCCM); 1 ふૈ, Piedmont: Ligurian Apennines, Capanne Superiori di Marcarolo, 900 m, 21.vii.2003, L. Baldizzone leg. (RCGF); 3 \&, Liguria: Ligurian Apennines, Maissana, road to Passo del Bocco di Bargone, 635-960 m, 18.v.2015, M. Guaschino leg. (RCCM); 1 ふै, Emilia-Romagna: Tuscan-Emilian Apennines, Bologna, Monte Pizzo, 1000 m, 5.vii.1970, A. Bastia leg. (RCCF); 1 त, 3 † Emilia-Romagna: Tuscan-Emilian Apennines, Bologna, Monte Grande, 1530 m, 8.vii.1987, C. Flamigni leg. (RCCF); 2 đ , 2 o , Emilia-Romagna: Tuscan-Emilian Apennines, Bologna, Corno alle Scale, Passo del Vallone, 1650-1750 m, 31.vii.1986, C. Flamigni leg. (RCCF); 2 ふ̊, 2 ㅇ, Emilia-Romagna: Tuscan-Emilian Apennines, Bologna, Corno alle Scale, 1650 m, 4.vii.1984, 10.vii.1986, 1945 m, 10.vii.1986, C. Flamigni leg. (RCCF); 1 ふ઼, Tuscany: Apuan Alps, under Monte Corchia, Passo Croce, 18.vi.1999, L. Dapporto leg. (ZSM). 
Diagnosis (Figs 4, 9, 14, 19): Forewing almost free of dark scales (except the costa and the terminal fascia). Hindwing with more dark scales than forewing, but lighter than in most specimens of the nominate subspecies. The dark terminal fascia is generally narrow in the forewing (wide in the form pedemontaria), absent or very reduced in the hindwing (also in the form pedemontaria). The underside is variable, but less contrasted and less sprinkled with black than in most specimens of the nominate subspecies. The taxon pedemontaria (Figs $4 \mathrm{~b}, 14 \mathrm{~b}$ ) is an individual form, sometimes prevalent in some places: it shows a wide, dark terminal fascia on the forewing and a weakly marked underside on the hindwing, which is orange-yellow, scattered with dark vertical stripes, with barely perceptible lighter radiating streaks.

In the female genitalia signum small $(0.8-0.9 \mathrm{~mm}$, exceptionally $1.2 \mathrm{~mm}$ in a female from the Apennines near Bologna: see Table 3). Bullae tympani with a roundish lobe (absent in a female from the same locality: see Table 3). The specimens from northern Piedmont (Graian and Pennine Alps) were not dissected.

Distribution. France SE, Italy (Piedmont, Liguria, Tuscany, Emilia-Romagna: see Fig. 2). According to Leraut (2009) its distribution in France is limited to the southern Alps; we have confirmation for the following departments: Drôme: Montagne de Chamouse (Skou and Sihvonen 2015: pl. 2, fig. 18c, e), Vaucluse, Alpes-de-Haute-Provence, Alpes-Maritimes, Var. In Piedmont it occurs mainly in the south, from the Maritime Alps to the Apennines; according to Flamigni et al. (2007) it occurs also further north, up to the Graian Alps and the surroundings of Biella (Pennine Alps); the specimens from the Biella area were examined (without dissection of the genitalia) by the first author during the preparatory work on the first volume on the Italian Ennominae. The geographic position would suggest that specimens from Corsica also belong to this subspecies: this will need to be verified through the examination of the collected material.

Molecular data. The two barcoded specimens (both from Italy) diverge from those of the taxon limbaria s. str. (from Germany and Upper Normandy) respectively by $1.2 \%$ (Ligurian Alps) and $1.6 \%$ (northern Apennines); however, they diverge from one another by $1.6 \%$ and cannot be regarded as a "common separate cluster".

Remarks. The distribution of the taxa delimbaria and rablensis in the northern Piedmont is similar to that of Crocota pseudotinctaria Leraut, 1999 and C. tinctaria (Hübner, 1799): delimbaria and pseudotinctaria occur in the surroundings of Biella, while rablensis and both pseudotinctaria and tinctaria occur further to the north-east, in Campello Monti (tinctaria also occurs in Lombardy, like rablensis). The analysis of the DNA of the northern Piedmontese populations could help to better understand the relationship between the three taxa present in this area ( $d e$ limbaria, anzascaria, rablensis); the barcoding of a specimen from Campello Monti was unfortunately not successful.

\section{Isturgia limbaria anzascaria (Staudinger, 1892)}

Fidonia limbaria var. anzascaria Staudinger, 1892, Dt. ent. Z. Iris 5: 198, [Italy, northern Piedmont]: Val d'Anzasca near Macugnaga.

Material examined. Italy: 1 ふ̋, Piedmont: Monte Rosa, Macugnaga, near Pecetto, 1400 m, 21.vii.1984, C. Flamigni leg. (RCCF). $1 \precsim 1$ \&, Piedmont: Monte Rosa, Macugnaga, under Alpe Bill, 1400-1600 m, 26.vii.1984, C. Flamigni leg. (RCCF). 
Diagnosis (Figs 5, 10, 15, 20). Large, light yellow. Forewing upperside almost free of dark scales (except the costa and the terminal fascia), hindwing upperside with a few dark scales. Forewing dark terminal fascia narrow in the male and reduced to a few blackish dots in the female according to the original description; this fascia is present in both sexes in our specimens, but it is relatively narrow in relation to their size. Hindwing dark terminal fascia rather narrow or reduced to a few scales, especially in the female. Hindwing underside yellow, scattered with a few dark vertical stripes; whitish radiating streaks present but not very evident. Although Prout (1915) and Wehrli (1940) reported also the ssp. rablensis from Macugnaga, our specimens from this locality correspond well with the description of Staudinger, differing from rablensis by the larger size (wingspan 27-30 $\mathrm{mm}$ in anzascaria, 23-26 $\mathrm{mm}$ in the Italian specimens of rablensis) and by the purest yellow, almost without dark scales; it will be possible to definitively confirm the validity of the subspecies examining a greater number of specimens.

In the only female examined signum large $(1.4 \mathrm{~mm})$. Bullae tympani without roundish lobe.

Distribution. Valle Anzasca (Italy: northern Piedmont), on the southern side of the Monte Rosa massif (Fig. 2).

Remarks. Not yet barcoded. The size of the signum and the absence of a roundish lobe in the bullae tympani indicate a greater similarity with rablensis and roraria, but the wing upperside is closer to delimbaria, but the hindwing has a dark terminal fascia.

\section{Isturgia limbaria rablensis (Zeller, 1868)}

Fidonia limbaria var. rablensis Zeller, 1868, Verh. zool.-bot. Ges. Wien 18: 587, [Italy, Friuli-Venezia Giulia]: Grafenlahn above Raibl [Cave del Predil] and below along the stream. At the time the locality Raibl was situated in Austria (Upper Carinthia).

Fidonia limbaria styriaca Schwingenschuss, 1911, Verh. zool.-bot. Ges. Wien 61 (1/2): (46), [Austria], Styria: Polster, near Prebichl [Präbichl], 1400-1600 m. Synonymy follows Huemer and Tarmann (1993). Also Huemer (2013) attributes the population of Styria to the taxon rablensis.

Material examined. Italy: $1 \hat{\jmath}, 1 \stackrel{\phi}{ }$, Piedmont: province of Verbania-Cusio-Ossola, Valstrona, Campello Monti, 1700

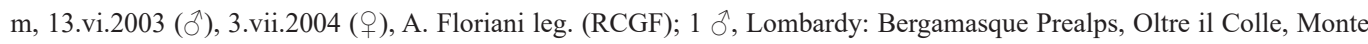
Menna, 1600 m, 22.vi.2013, R. Taverna leg. (RCCF); 1 ㅇ, Lombardy: Bergamasque Prealps, Camerata Cornello, towards Passo Grialeggio, 23.vii.2010, M. Massaro and W. Zucchelli leg. (MSMB); 1 o, Lombardy: Bergamasque Alps, Ardesio, 1400 m, 28.iv.2007, W. Zucchelli leg. (MSMB); 1 ô, Trentino-Alto Adige: Monte Baldo, San Valentino, 1300 m, 30.vi.1980, S. Camporesi leg. (RCGF); 3 \%, Trentino-Alto Adige: Monte Baldo, Monte Altissimo, Rifugio Graziani, about 1600 m, 3.vii.2005, Morandini leg. (RCCM); 1 ㅇ, Trentino-Alto Adige: Brentonico, [Monte Baldo], 1700 m, 8.vii.2001, E.O. Bonora leg. (RCCM); 1 đ̃, Trentino-Alto Adige/Veneto: Monte Baldo, Cima Valdritta, 1400-1600 m, mid v.1966, J.

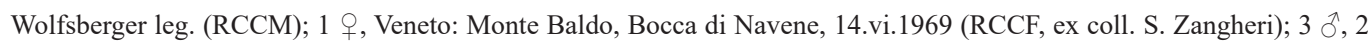
+, Veneto: Monte Baldo, Rifugio Novezza, 1600 m, 2.vi.2000/17-22.v.2001 ex ovo, 1550 m, 3.vi.1999, E. Friedrich leg. (RCEF) (digital images of both sides on Lepiforum); 2 ऽ, 2 ㅇ, Friuli-Venezia Giulia: Carnic Prealps, Barcis, Prescudin, 600 m, 6.vi.1973, 8.vi.1976, 800 m, 9.vi.1973, Morandini leg. (RCCM); 1 § 3 \&, Friuli-Venezia Giulia: Carnic Prealps, Monte Festa, 1200 m, 7.vi.1972, C. Morandini leg. (RCCM); 1 §̃, 1 o, Friuli-Venezia Giulia: Carnic Prealps, Monte San Simeone, 1200 m, 22.vi.1972, Morandini leg. (RCCM); 1 ふ̋, Friuli-Venezia Giulia: Julian Prealps, Matajur, 1600 m, $17 . v i .1989$, L. Morin leg. (RCCM); 1 §̊, Friuli-Venezia Giulia: Julian Prealps, Matajur, 1500 m, 19.vi.2014, photo H. Deutsch (digital images of both sides on Lepiforum); 3 q, Friuli-Venezia Giulia: Julian Alps, Jof Montasio, 1700 m, 18.vii.1972, 1600 m, 1.vii.1973, C. Morandini leg. (RCCM). Slovenia: 2 đ, 1 \&, Julian Alps, Bovec, Mangart, 1700 m, 28.vi.2003, E. Friedrich leg. (RCEF) (digital images of both sides on Lepiforum). Macedonia: 2 ๙ , Baba Planina [Baba Mountain], Pelister, Golemo ezero [Large Lake], 22-25.vi.1965, J. Karneluti leg. (RCCM). Greece: 2 ঐ, 2 †, Western Macedonia: surroundings of 
Pisoderi, 1950 m, 2-3.vii.2019, V. Valenta leg. (RCCF). Bulgaria: 1 §ै, 1 q, Sofia: Vitoša [Vitosha], 1500 m, $11 . v i .1972$, V. Felix leg. (RCCM); 1 స, 1 †, Sofia: Vitoscha [Vitosha], 2.vii.2002 (RCGF). Romania: 1 o, 1 †, Dâmbovița County: Southern Carpathians, Bucegi Mountains, Valea Jepii, 1800 m, 7.vi.2007, S. and. Z. Kovacs leg. (ZSM); 1 ô, Buzău County: Eastern Carpathians, Nemira Mountains, Lassuag, 1100 m, 22.vi.1996, S. and.Z. Kovacs leg. (ZSM).

The underside of a male from Gitschtal (Austria: Carinthia) is figured by Wieser (2008: fig. 16); colour images of specimens from Serbia (as I. limbaria and as I. roraria) are shown on the website Alciphron (2019).

Diagnosis (Figs 6, 11, 16, 21). Upperside more or less scattered with groups of dark scales (or dark lines short or longer), scattered or more dense; in some specimens (mainly in the westernmost part of the distribution area) there are only a few dark scales in the forewing (except on the costa and in the terminal fascia), a little more dense in the hindwing; in other specimens (also among the most western ones) both wings are scattered with dense groups of dark scales; dark terminal fascia generally narrow, wider in Bulgarian specimens, in the hindwing it can be present or absent. Underside with fore- and hindwings more or less different in pattern and colour (identical in roraria $\mathrm{s}$. str.): both wings scattered with dark vertical lines, but colour generally more orange-yellow in the forewing, more whitish yellow in the hindwing, whitish radiating streak(s) of the hindwing present (sometimes barely perceptible).

In the female genitalia signum large $(1.1 \mathrm{~mm}$, exceptionally $1.6 \mathrm{~mm})$. Bullae tympani without roundish lobe.

Distribution. Northern Italy (see Fig. 2), Austria (Huemer, 2013: Carinthia, Styria), Slovenia, Serbia, Macedonia, Kosovo, Albania, Greece (Western Macedonia), Bulgaria, Romania. The taxon rablensis was recorded from Albania (Djalica e Lumës) by Rebel and Zerny (1934) and by Povolný and Moucha (1957: fig. 57); the first two authors also mention Žljeb in Kosovo; its occurrence in Romania is confirmed from the Bucegi Mountains (see also Popescu-Gorj (1995)) and the Nemira Mountains; the records of $I$. roraria s.l. from other areas of Romania (in particular from the Cluj-Napoca area: cf. Rákosy et al. (2016)) must be verified by examining the underside of the specimens. The species also occurs in Croatia and Bosnia and Herzegovina (Skou and Sihvonen 2015), but we have not examined material from these countries. Viidalepp (1996) attributes the populations from Transcaucasus (Georgia) to this subspecies (as I. roraria rablensis).

Molecular data. The westernmost populations (Lombardy and Monte Baldo in Italy, Carinthia in Austria) correspond to a separate BIN, at a distance of $2.0 \%$, while all the others (from the Julians Alps to Bulgaria and Romania) share the same BIN of the following subspecies; however, no constant morphological character corresponds to these genetic differences and it is not possible to distinguish the specimens of the more western regions from those of the Julian Alps (both populations are very variable). The exact border between these two BINs is not known, since no specimens from the Carnic Prealps have been barcoded. Three specimens from Romania diverge into a separate cluster, but they are morphologically very similar to those from Bulgaria.

\section{Isturgia limbaria roraria (Fabricius, 1776) stat. nov.}


pau [Opava] [infrasubspecific: form without dark terminal fascia].

Fidonia roraria ab. nigrescens Preissecker, 1923, Verh. zool.-bot. Ges. Wien 72: (95), [Lower Austria]: Dunkelsteinerwald, near Ernsthof [infrasubspecific].

? Cleogene ostrogovichi CARAdja, 1930, Bull. Sect. scient. Acad. roum. 13 (3): 52, [Romania], Siebenbürgen [Transylvania]: Cluj, [Galişer Hill]. Synonym of roraria according to Rákosy et al. (2016), but it could instead be synonym of rablensis if the occurrence of this taxon in the Cluj-Napoca area was ascertained.

Isturgia roraria ab. stehliki Bretschneider, 1954, Ent. Z. 64: 41, Germany, [Saxony-Anhalt], Dessau [infrasubspecific: almost completely black form, obtained from a F2 generation, bred from normal-coloured roraria parents].

Material examined. Germany: $1 \hat{\jmath}$, Saxony-Anhalt: Bitterfeld, Marke, $0.5 \mathrm{~km}$ east the motorway exit Dessau-Süd, $85 \mathrm{~m}$, 24.v.2012, J. Gelbrecht leg. (ZSM); 3 đ 3 ㅇ, Saxony-Anhalt: Dessau, Möst W, 80 m, 19.V.2016, 19.v.2016/31.iii-14. iv.2017 ex ovo, E. Friedrich leg. (RCEF) (digital images of both sides on Lepiforum); 3 $\uparrow, 3$, Bavaria: Spalt (and surroundings), 18.v.2004, 26.v.2005 ex ovo, 22.vi.2007 ex ovo, 3.v.2008 ex ovo, 6.v.11 ex ovo, 27.iv.2012 ex ovo, A. Zoglauer leg. (RCCF, RCCM); 1 §̋, Bavaria: Mittelfranken, Nürnberger Land, Leinburg, Wolfsgrube Ost, 405 m, 20.vii.2010, A. H. Segerer leg. (ZSM). Austria: 1 ô, 1 \&, Lower Austria: Pottenstein, 31.v.1930, 21.vi.1930, R. Kitschelt leg. (NHMW) (digital images of both sides on Lepiforum). Czech Republic: 1 đ), Moravia: Vápenky, 13.v.2006 ex ovo, J. Uñčár̆ leg. (RCCM); 1 đ̊, Moravia: Bílé Karpaty [White Carpathians], Machová, 1996 ex ovo, E. Lohočka leg. (RCCM). Slovakia: 1 \&, Handlová, iv-2003 ex ovo on Genista, I. Richter leg. (RCCM).

Colour images of specimens from Poland are shown by Blaik (2003) (variability of upperside), Blaik and Malkiewicz (2003) (upperside and underside) and on the website Lepidoptera Mundi (2019).

Diagnosis (Figs 7, 12, 17, 22). Ground colour of the upperside deep yellow or orange, scattered with dark vertical lines; the dark terminal fascia (when present) is generally wide; however, the upperside is often identical to that of the previous subspecies and the differentiation from it is possible only by examining the underside. On the underside fore- and hindwing with identical colour and pattern: ground colour orange-yellow or orange scattered with dark vertical stripes (a little more dense on the hindwings); hindwing without a trace of whitish radiating streaks (sometimes a streak of a slightly lighter yellow, for example in specimens from Poland and Slovakia).

On the upperside, the dark terminal fascia is variable: according to Povolný and Moucha (1957) in Slovakia most of the individuals from the Ore Mountains have this fascia less developed than those from Vihorlat Mountains and in the first locality it is absent in a high percentage of females (but also males). In Poland (Blaik 2003) this fascia is wide and always present in the males (more or less distinct), almost always indistinct or absent in the females; specimens were collected in a locality with a large area of the forewing upperside without dark markings.

In the female genitalia signum large (1.2-1.4 mm). Bullae tympani without roundish lobe.

Distribution. North-eastern and south-eastern Germany (cf. Skou and Sihvonen 2015: map on page 99), Austria (Huemer 2013: Lower Austria), southern Poland, Czech Republic, Slovakia, north-eastern Hungary. For Romania, see the previous subspecies. Viidalepp (1996) attributes to roraria s. str. the populations from Ukraine, south-eastern Russia and southern Urals.

\section{Acknowledgements}

We are grateful to Axel Hausmann (SNSB-Bavarian State Collection of Zoology, Munich, Germany), who examined the specimens from the ZSM SNSB collection and gave us information on genetic data. We also thank Jörg Gelbrecht (Königs Wusterhausen, Germany) for the information and drawings on the preimaginal stages, Carlo Morandini (former director of the Friulian Museum of Natural History, Udine, Italy), Guido 
Govi (Forlì, Italy) and Melania Massaro and Rossana Pisoni (Museo Civico di Scienze naturali “E. Caff”, Bergamo, Italy) for loan of material and the Canadian Centre for DNA Barcoding (Ontario, Canada) that carried out the DNA analyses, as well as all museum curators for providing material for our study.

\section{References}

Alciphron (2019) Alciphron. http://alciphron.habiprot.org.rs/ [Accessed 4.vii.2019]

Beshkov S (2001) Lepidoptera species (Macrolepidoptera) recorded and reported from the Western Stara Planina Mountain, NW Bulgaria. Entomologica romanica 5[2000]: 11-43. http://er.lepidoptera.ro/05_2000/ ER05200002_Beshkov.pdf

Blaik T (2003) Notes on the occurrence of Isturgia roraria Fabricius, 1777 (Lepidoptera: Geometridae) in Poland with remarks on its ecology, biology and variability. Polish Journal of Entomology 72: 23-37.

Blaik T, Malkiewicz A (2003) Morphology of larval and pupal stages of Isturgia roraria (Fabricius, 1777) (Lepidoptera: Geometridae). Annales Zoologici 53(2): 245-258.

Buckler W (1897) The larvae of the British butterflies and moths VII. Porritt G.T., London, 191 pp. [plates CVI-CXXVII]

deWaard JR, Ivanova NV, Hajibabaei M, Hebert PDN (2008) Assembling DNA barcodes: analytical protocols. In: Martin CC (Ed.) Environmental Genomics. Humana Press, Totowa NJ, 275-293. https://doi. org/10.1007/978-1-59745-548-0_15

Fajčík J, Slamka F (1996) Motýle strednej Európy I, Die Schmetterlinge Mitteleuropas I. F. Slamka, Bratislava, 113 pp. [plates 1-21, I-XX]

Flamigni C, Fiumi G, Parenzan P (2007) Lepidotteri Eteroceri d'Italia, Geometridae Ennominae I. Natura Edizioni Scientifiche di Alfonso Iorio, Bologna, $384 \mathrm{pp.}$

Flamigni C, Fiumi G, Parenzan P (2016) Lepidotteri Eteroceri d'Italia, Geometridae Ennominae II. Natura Edizioni Scientifiche di Alfonso Iorio, Bologna, 576 pp. [plates 1-32]

Ford EB (1972) Moths. New Naturalist ( $3^{\text {rd }}$ edn). Collins, London, 266 pp.

Hacker H (1999) Die Typen der von E. J. Ch. Esper (1742-1810) in seinem "Die Schmetterlinge in Abbildungen nach der Natur" beschriebenen Bombycoidea, Drepanoidea, Geometroidea, Hepialoidea, Lasiocampoidea, Noctuoidea, Pyraloidea, Tineoides (Lepidoptera) II. Esperiana, 7: 443-461. http://www. esperiana.net/mediapool/86/862516/data/Esper_Typen_2.pdf

Hausmann A (2001) Introduction, Archiearinae, Orthostixinae, Desmobathrinae, Alsophilinae, Geometrinae. In: Hausmann A (Ed.) The Geometrid Moths of Europe 1. Apollo Books, Stenstrup, 282 pp. [plates 1-8]

Huemer P (2013) Die Schmetterlinge Österreichs (Lepidoptera). Systematische und faunistische Checkliste. Studiohefte 12, Tiroler Landesmuseen-Betriebsgesellshaft m.b.H, Innsbruck, 304 pp.

Huemer P, Tarmann G (1993) Die Schmetterlinge Österreichs (Lepidoptera). Systematisches Verzeichnis mit Verbreitungsangaben für die einzelnen Bundesländer. Beilageband $5 \mathrm{zu}$ den Veröffentlichungen des Museum Ferdinandeum 73, Innsbruck, 224 pp. https://www.zobodat.at/stable/pdf/VeroeffFerd_73_BL_0001-0224.pdf

Ivanova NV, deWaard JR, Hebert PDN (2006) An inexpensive, automation-friendly protocol for recovering high-quality DNA. Molecular Ecology Notes 6: 998-1002. https://doi.org/10.1111/j.14718286.2006.01428.x

Kimura M (1980) A simple method for estimating evolutionary rates of base substitutions through comparative studies of nucleotide sequences. Journal of Molecular Evolution 16: 111-120. https://doi.org/10.1007/ BF01731581

Lehmann L (1990) Beitrag zur Makrolepidopterenfauna Südwestbulgariens mit Bemerkungen zur subspezifischen Gliederung (Lepidoptera). Atalanta 21 (1/2): 121-138. https://www.zobodat.at/pdf/Atalanta_21_0121-0138.pdf

Lempke BJ (1952) Catalogus der Nederlandse Macrolepidoptera XI. Tijdschrift voor Entomologie, 95 (3/4): 197-319. https://archive.org/details/tijdschriftvoor951953nede/page/n427 
Lepidoptera Mundi (2019) All the World's Butterflies and Moths in one place! https://lepidoptera.eu/ [Accessed 4.vii.2019]

Lepiforum (2019) Lepiforum. http://www.lepiforum.de/ [Accessed 4.vii.2019]

Lepi’Net (2019) Les Carnets du Lépidoptériste Français. http://www.lepinet.fr/ [Accessed 4.vii.2019]

Leraut P (2009) Moths of Europe 2. Geometrid moths. N.A.P. Editions, Verrières le Buisson, France, 808 pp.

Mazzei P, Morel D, Panfili R (2019) Moths and Butterflies of Europe and North Africa. https://www.leps.it/ [Accessed 4.vii.2019]

Müller B, Erlacher S, Hausmann A, Rajaei H, Sihvonen P, Skou P (2019) Ennominae II. In: Hausmann A, Sihvonen P, Rajaei H, Skou P (Eds) The geometrid moths of Europe 6. Brill, Leiden, 906 pp. https://doi. org/10.1163/9789004387485

Patočka J (2004) Die Puppen der mitteleuropäischen Spanner aus der Unterfamilie Ennominae (Lepidoptera: Geometridae), 2. Teil. Linzer Biologische Beiträge 36(1): 315-388. https://www.zobodat.at/pdf/ LBB_0036_1_0315-0388.pdf

Popescu-Gorj A (1995) Lepidopterans from the surroundings.of the town Sinaia and from Bucegi Mountains (Romania). Travaux du Muséum National d'Histoire Naturelle "Grigore Antipa" 35: 161-220.

Povolný D, Moucha J (1957) Kritische Bemerkungen zu einigen Geometridengattungen (Lep., Geometridae). Acta Entomologica Musei Nationalis Pragae 31: 125-143. [plates I-VIII]

Povolný D, Moucha J (1959) Kritische Bemerkungen zu einigen Geometridengattungen II (Lep., Geometridae: Narraga, Isturgia, Epelis). Acta Entomologica Musei Nationalis Pragae 33: 453-460. [figures 3-15]

Prout LB (1915) 145. Genus: Isturgia Hbn. In: Seitz A (Ed.) The Macrolepidoptera of the World (Vol. 4). Alfred Kernen, Stuttgart, 397-398. https://www.biodiversitylibrary.org/item/110532\#page/415/mode/1up

Rákosy L, Stüning D, Stănescu M, Sommerer M (2016) The systematic position of Palaeocrocota ostrogovichi (Caradja, 1930) (Lepidoptera: Geometridae, Ennominae). Entomologica romanica 20: 63-67. http:// er.lepidoptera.ro/20_2016/ER20201603_Rakosy_etal.pdf

Ratnasingham S, Hebert PDN (2007) BOLD: The Barcode of Life Data System. (http://www.barcodinglife. org). Molecular Ecology Notes 7: 355-364. https://doi.org/10.1111/j.1471-8286.2007.01678.x

Rebel H, Zerny H (1934) Wissenschaftliche Ergebnisse der im Auftrage und mit Kosten der Akademie der wissenschaften in Wien im Jahre 1918 entsendeten Expedition nach Nordalbanien. Die Lepidopterenfauna Albaniens (mit Berücksichtigung der Nachbargebiete). Denkschriften der Akademie der Wissenschaften in Wien. Mathematisch-Naturwissenschaftliche Klasse 103[1931]: 37-161. [plate I and map] https://www. zobodat.at/pdf/DAKW_103_0037-0161.pdf

Reser L (2010) Geometridae. In: SwissLepTeam, Die Schmetterlinge (Lepidoptera) der Schweiz. Eine kommentierte, systematisch-faunistische Liste. Fauna Helvetica 25, Centre suisse de cartographie de la faune \& Schweizerische Entomologische Gesellschaft, Neuchâtel, 126-142, 215-247.

Saitou N, Nei M (1987) The neighbor-joining method: a new method for reconstructing evolutionary trees. Molecular Biology and Evolution 4: 406-425.

Scoble MJ [Ed.] (1999) Geometrid moths of the World: a catalogue (Vols 1 and 2). CSIRO Publishing and Apollo Books, Collingwood (Australia), Stenstrup (Denmark), 1016 pp. [129 pp. of index] https://doi. org/10.1071/9780643101050

Skinner B (1984) Colour identification guide to moths of the British Isles. Viking, Harmondsworth, England, $267 \mathrm{pp}$.

Skou P, Sihvonen P (2015) Ennominae I. In: Hausmann A (Ed.) The Geometrid Moths of Europe 5. Brill, Leiden, $657 \mathrm{pp}$.

UKmoths (2019) UKmoths. http://www.ukmoths.org.uk/ [Accessed 4.vii.2019]

Viidalepp J (1996) Checklist of the Geometridae (Lepidoptera) of the former U.S.S.R.. Apollo Books, Stenstrup, $111 \mathrm{pp}$. 
Wehrli E (1940) 92. (144.) Gattung: Isturgia Hbn. In: Seitz A (Ed.) (1934-1954) Die Gross-Schmetterlinge der Erde, Supplement zu Band 4. Alfred Kernen Verlag, Stuttgart, 394-395. https://www.biodiversitylibrary.org/ia/diegrossschmette04seit_0\#page/404/mode/2up

Wieser C (2008) Die Felssteppenrasen des Gitschtales - ein "hot spot" an Biodiversität bei Schmettterlingen in Kärnten. Rudolfinum - Jahrbuch des Landesmuseums für Kärnten 2006: 255-283. https://www.zobodat.at/stable/pdf/Rudolfinum_2006_0255-0283.pdf

Zeller PC (1868) Beitrag zur Kenntniss der Lepidoptern-Fauna der Umgegend von Raibl in Oberkärnthen und Preth im angrenzenden Küstengebiet. Verhandlungen der kaiserlich-königlichen zoologisch-botanischen Gesellschaft in Wien 18(3/4): 563-628. https://www.zobodat.at/pdf/VZBG_18_0563-0628.pdf

\section{Appendix I}
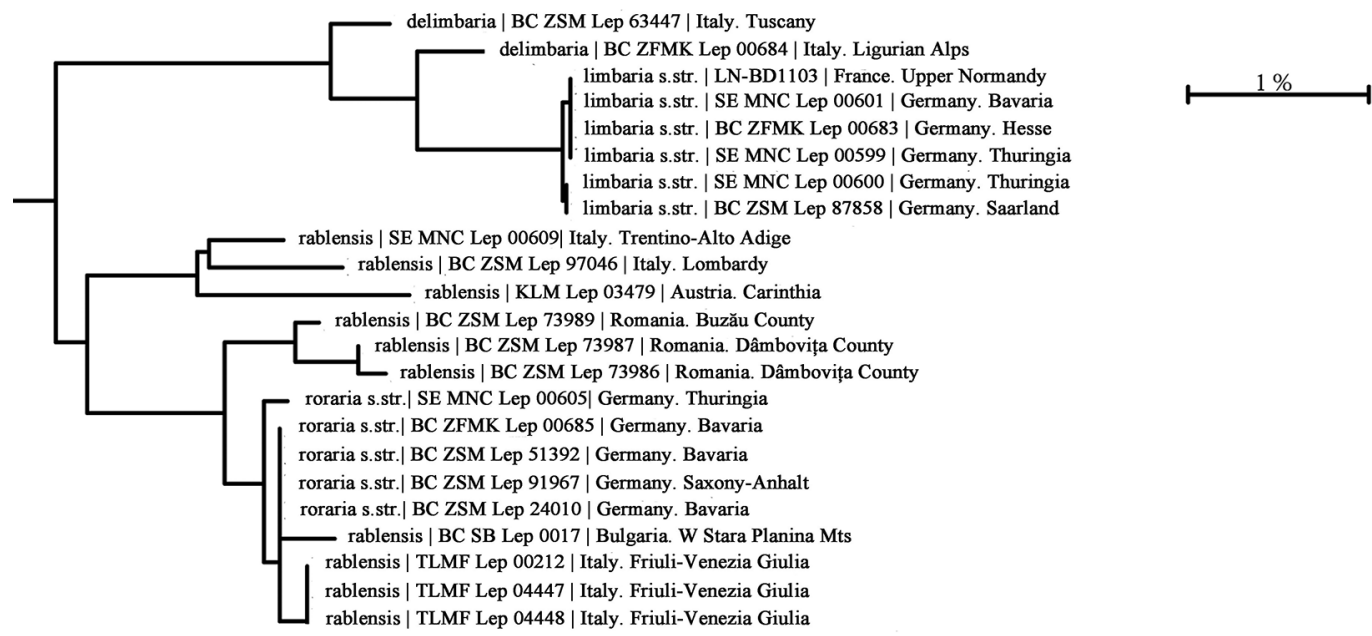

Figure A1. Neighbour joining tree (Kimura 2-parameter distance model for COI-5P marker, data from BOLD data systems) for 23 European specimens. Terminals with taxon, specimen ID and geography. 